\title{
Bouguer Gravity of Arkansas
}

U.S. GEOLOGICAL SURVEY PROFESIONAL PAPER 1474

Prepared in cooperation with the

Arkansas Geological Commission

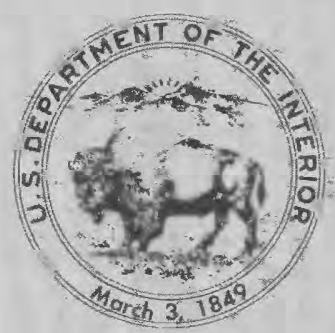




\title{
Bouguer Gravity of Arkansas
}

\author{
By JOHN D. HENDRICKS
}

U.S. GEOLOGICAL SURVEY PROFESSIONAL PAPER 1474

Prepared in cooperation with the Arkansas Geological Commission

$A$ description and analysis of the Bouguer gravity anomalies of Arkansas, with emphasis on tectonic and igneous history of the region

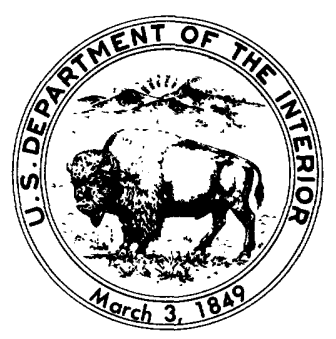




\section{DEPARTMENT OF THE INTERIOR \\ DONALD PAUL HODEL, Secretary}

\section{U.S. GEOLOGICAL SURVEY}

Dallas L. Peck, Director

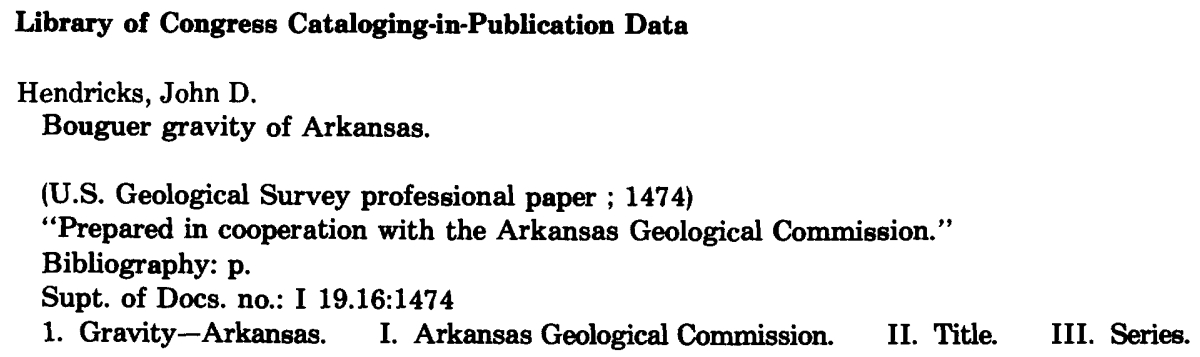

For sale by the Books and Open-File Reports Section, U.S. Geological Survey, Federal Center, Box 25425, Denver, CO 80225 


\section{CONTENTS}

Abstract

Introduction

Physiographic divisions and gravity patterns $\ldots \ldots \ldots \ldots$

Ozark Plateaus . . . . . . . . . . . . . . . . .

General geology

Gravity anomalies of the Arkansas Ozarks ......

Gravity anomalies and faulting ..............

Ouachita Mountains and Arkansas Valley . . . . . . . Stratigraphy $\ldots \ldots \ldots \ldots \ldots \ldots \ldots \ldots$ Bouguer gravity of the Ouachita Mountains-

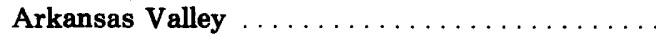
Tectonic model for the Ouachita system . . . . . .

Mississippi embayment $\ldots \ldots \ldots \ldots \ldots \ldots \ldots \ldots$ Geologic history $\ldots \ldots \ldots \ldots \ldots \ldots \ldots \ldots$

Tectonic history of the Mississippi embayment ... Gravity modeling . . . . . . . . . . . . . . .

Ouachita structure at depth in the Mississippi

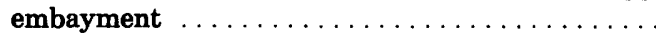

West Gulf Coastal Plain $\ldots \ldots \ldots \ldots \ldots \ldots \ldots \ldots$

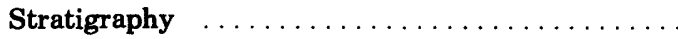
Gravity patterns

\begin{tabular}{r|r} 
Page & 1 \\
1 \\
1 \\
2 \\
2 \\
2 \\
3 \\
4 \\
4 \\
4 \\
\\
6 \\
7 \\
13 \\
13 \\
14 \\
14 \\
15 \\
16 \\
16 &
\end{tabular}

Gravity anomalies resulting from Phanerozoic igneous activity Geophysical anomalies associated with exposed igneous

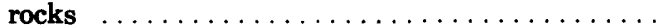

Little Rock complex . . . . . . . . . . . . . . . .

Magnet Cove Complex ..................

Potash Sulphur Springs intrusive body ........

Peridotite of Pike County or kimberlite at Murfreesboro Geophysical anomalies associated with igneous rocks in drill holes $\ldots \ldots \ldots \ldots \ldots \ldots \ldots \ldots \ldots \ldots \ldots, 21$

Peridotite near Rison in Cleveland County ...... 21

Dumas anomaly ...................... 23

Diabase(?) in Drew County .............. 23

Chicot and Ashley Counties anomaly ......... 23

Covington and Millington, Tennessee ......... 24

Suspected intrusive bodies .................. 24

Associated anomalies near Rison $\ldots \ldots \ldots \ldots \ldots, 24$

Newport anomaly ................... 24

Jonesboro, Marmaduke, Sedgwick, and Walnut Ridge $\quad 27$

Piggott "Low" ..................... $\quad \mathbf{2 7}$

Relation of igneous intrusions to proposed tectonic model 27

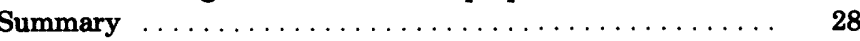

References cited $\ldots \ldots \ldots \ldots \ldots \ldots \ldots \ldots \ldots \ldots \ldots$

\section{ILLUSTRATIONS}

[Plates are in pocket]

Plate 1. Map showing Bouguer gravity and generalized geology of Arkansas.

2. Map showing interpreted Bouguer anomalies and tectonic elements of Arkansas.

Figure 1. Histogram of implied sedimentation rates for exposed Paleozoic rocks in the Ouachita Mountains ...........

2. Regional Bouguer gravity map of the southeastern United States $\ldots \ldots \ldots \ldots \ldots \ldots \ldots \ldots \ldots \ldots \ldots$

3. Graph and cross section of two-dimensional gravity model in western Arkansas $\ldots \ldots \ldots \ldots \ldots \ldots \ldots \ldots$

4. Maps and cross sections showing hypothetical tectonic evolution of the southern North American continent from late

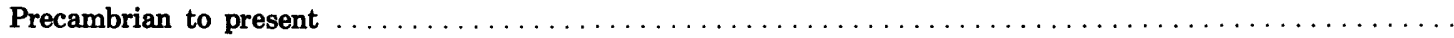

5-8. Graphs and cross sections showing:

5. Two-dimensional gravity model from Yellville, Arkansas, to Scottsboro, Alabama ............. 1 .

6. Gravity and magnetic model of the igneous complex at Little Rock $\ldots \ldots \ldots \ldots \ldots \ldots \ldots \ldots \ldots \ldots$

7. Gravity and magnetic model of the Magnet Cove, Arkansas, area $\ldots \ldots \ldots \ldots \ldots \ldots \ldots \ldots \ldots \ldots$

8. Gravity and magnetic model of the Newport, Arkansas, area $\ldots \ldots \ldots \ldots \ldots \ldots \ldots \ldots \ldots \ldots \ldots \ldots$

9. Map of the Newport, Arkansas, area showing distribution of the hypothetical $+0.2 \mathrm{~g} / \mathrm{cm}^{3}$ body from figure $8 \ldots 26$

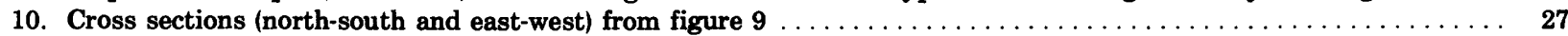

\section{TABLES}

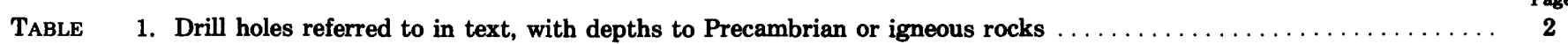

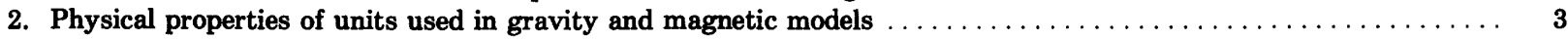





\title{
BOUGUER GRAVITY OF ARKANSAS
}

\author{
By JOHN D. HENDRICKS
}

\begin{abstract}
The Bouguer gravity anomaly patterns in Arkansas correspond very well with the physiographic provinces and sections of the State. These provinces and sections are, in turn, defined by the limits of separate tectonic events that span the range in time from late Precambrian to Tertiary. Bouguer gravity values range from +37 to $-107 \mathrm{mGal}$ within the State. The highest values are associated with ultrabasic alkalic igneous intrusions and the lowest values correspond to the Ouachita Mountains and Arkansas Valley, which were formed during the Ouachita orogeny. Variation in seismically determined crustal thickness from north to south is also reflected in the gravity anomaly; that is, the higher gravity values in the southern part of the State reflect a thinner crust than that in the northern part.

Speculation on the tectonic history of the region has led to the proposal of a model in which a series of tensional and compressional events (Wilson cycles) have formed the major structural features. These elements, in turn, controlled the location of magmatic events.

Regional profiles are constructed that will satisfy both the proposed tectonic model and observed gravity anomalies. Isolated gravity and magnetic anomalies, thought to result from the presence of subsurface igneous bodies, are also modeled and provide an estimate of the shape, density, and magnetic susceptibility of these bodies.
\end{abstract}

\section{INTRODUCTION}

Gravity measurements obtained within the State of Arkansas have been compiled and plotted as a contour map of the simple Bouguer anomaly (Hendricks and others, 1981). The purpose of this report is to interpret the major anomalies shown on this map and to relate the anomalous patterns and trends to tectonic events.

The Bouguer gravity map of Arkansas (pl. 1) is a direct reduction of the map of Hendricks and others (1981), which represents the compilation of more than 17,000 measurements obtained by the U.S. Geological Survey and Brown Geophysical Company. ${ }^{1}$ The nearly 14,000 gravity observations made by the U.S. Geological Survey for this report were obtained from 1973 to 1978 . Readings were made on points of known elevation and position. The gravity meters used have accuracies greater than $0.1 \mathrm{mGal}$ (milligal). All readings were tied to the world relative gravity reference network

\footnotetext{
${ }^{1}$ Any use of trade names is for descriptive purposes only and does not imply endorsement by the U.S. Geological Survey.
}

stations (ACIC, 1973) at Little Rock and Bald Knob, Ark., through a system of 41 supplemental base stations. Station density is highest in the east and southern parts of the State, averaging about 1 station/ $6 \mathrm{~km}^{2}$, while in the northern and western parts of the State, it averages 1 station $/ 20 \mathrm{~km}^{2}$. On plate 1 a rock density of $2.67 \mathrm{~g} / \mathrm{cm}^{3}$ was assumed for the Bouguer correction.

Corrections for instrumental drift, elevation changes, latitude differences, and Earth curvature were applied to all readings. The resulting simple Bouguer gravity values are accurate to greater than $0.5 \mathrm{mGal}$. Terrain corrections were not applied to these observations but range from a maximum of about $4.0 \mathrm{mGal}$ for stations nearest major topographic features in the Ozark Plateaus and Ouachita Mountains regions to $0 \mathrm{mGal}$ in the Mississippi embayment. None of the gravity anomalies discussed in this report result from the effect of terrain differences.

Published gravity maps that include all or parts of Arkansas, but are not included on plate 1, are those of Malamphy and Vallely (1944), Lyons (1961), Woollard and Joesting (1964), Phelan (1969), and the Society of Exploration Geophysicists (1982). In addition to the gravity maps, a total field aeromagnetic map covering northeast and central Arkansas (Hildenbrand and others, 1981) is available, and data from that map are used in this report to supplement interpretation of gravity anomalies.

\section{ACKNOWLEDGMENTS}

This report was prepared in cooperation with the Arkansas Geological Commission. I wish to thank Norman F. Williams, Director of the Commission, and all staff members who provided laboratory, field, and logistical support for collection of the data presented herein. G.R. Keller, University of Texas at El Paso, provided supplemental gravity data which allowed a composite gravity map of Arkansas to be made. The following U.S. Geological Survey personnel assisted in production of the Bouguer gravity map of Arkansas: Boyd R. Haley, who directed and provided critical 
assistance during the survey; Tom Hildenbrand and Bob Kucks, who assisted in compiling and modeling gravity anomalies; Bruce Campbell, Tucker Hentz, Dave Lumbert, Gary Mason, James Puckette, Robert Rozen, Tracy Shrier, and Jerry Trudnak, who assisted in collecting gravity data; Howard Oliver and Stephen Robbins provided critical comments to this manuscript.

\section{PHYSIOGRAPHIC DIVISIONS AND GRAVITY PATTERNS}

The State of Arkansas consists of five physiographic provinces and sections, and there exists a distinct relation between these regions and the Bouguer gravity patterns (pl. 2). The gravity field of each province will be discussed separately and then summarized as to interarea associations.

\section{OZARK PLATEAUS}

\section{GENERAL GEOLOGY}

The Ozark Plateaus physiographic province (Fenneman, 1946) occupies an area of approximately 30,000 $\mathbf{k m}^{2}$ in northwest and north-central Arkansas. This province is referred to as the Ozark region or Ozarks in this report. Surface rocks of the Ozark region range in age from Early Ordovician in the north to Pennsylvanian in the south and are entirely sedimentary in nature. These sedimentary beds are generally flat lying or dip gently to the south except where disrupted by local faulting and folding. Individual formations maintain a fairly uniform thickness except for erosional effects. The underlying Precambrian basement complex thus deepens from north to south. Six drill holes, in or directly adjacent to the Arkansas Ozark Plateaus province, have penetrated the entire Paleozoic section and bottomed in rocks of granitic composition (pl. 2).

In the northeast part of the Arkansas Ozarks, estimates made from aeromagnetic surveying (Hildenbrand and others, 1980) indicate depths to basement of less than $1 \mathrm{~km}$. In southwest Missouri the top of the Precambrian surface is at a depth of about $0.5 \mathrm{~km}$ (Kisvarsanyi, 1974). South of the Ozark-Arkansas Valley division (pl. 2; table 1), in extreme western Arkansas, the Shell Oil No. 1, West Coal and Mining well (well $a$ ) penetrated granite(?) at a depth of about $3.3 \mathrm{~km}$. It appears, therefore, as indicated by stratigraphic projections, that the sedimentary section increases in thickness from less than $1 \mathrm{~km}$ along the ArkansasMissouri border to about $2.5 \mathrm{~km}$ in the southern Ozark region.

\begin{tabular}{|c|c|c|c|}
\hline Well & Well name & $\begin{array}{l}\text { Depth to } \\
\text { Precambrian } \\
\text { or igneous } \\
\text { rocks } \\
\text { (meters) }\end{array}$ & Rock type \\
\hline $\begin{array}{l}a \\
b\end{array}$ & $\begin{array}{l}\text { Shell Oil No. 1, West Coal and Mining } \\
\text { Shafer Oil and Refining, Youngblood } \\
\text { No. } 1 \text {. }\end{array}$ & $\begin{array}{r}3056 \\
687\end{array}$ & $\begin{array}{l}\text { Granite(?). } \\
\text { Pyroxenite. }\end{array}$ \\
\hline$c$ & $\begin{array}{l}\text { Arkansas Natural Gas Corp., Tate } \\
\text { No. } 1 \text {. }\end{array}$ & 1085 & Peridodite. \\
\hline$d$ & $\begin{array}{l}\text { Columbian Gas Co., Victoria Cross } \\
\text { Lumber Co. No. } 1 .\end{array}$ & 1486 & Normal syenite. \\
\hline $\boldsymbol{e}$ & Curtis Kinard, T.C. Deal No. $1 \ldots \ldots$ & 1326 & Diabase(?). \\
\hline$f$ & Lion Oil Co., Reap No. $1 \ldots \ldots$ & 1281 & $\begin{array}{l}\text { Undescribed } \\
\text { igneous. }\end{array}$ \\
\hline$g$ & $\begin{array}{l}\text { A. Plummer, Crossett Lumber Co. } \\
\text { No. } 1 .\end{array}$ & 1000 & $\begin{array}{l}\text { Volcanic } \\
\text { breccia. }\end{array}$ \\
\hline $\boldsymbol{h}$ & Lion Oil Co., No. 1 Bateman & 900 & Normal syenite. \\
\hline$i$ & Pure Oil Co., McGregor No. 1 & 695 & Syenite. \\
\hline
\end{tabular}

The Ozark Paleozoic section is composed mainly of limestone, dolomite, and shale with minor sandstone. Density determinations have been made on six core samples of the Powell Dolomite (Lower Ordovician) from the Arkansas Ozarks (table 2). These range from 2.70 to $2.82 \mathrm{~g} / \mathrm{cm}^{3}$ averaging $2.74 \mathrm{~g} / \mathrm{cm}^{3}$. Three samples of the Upper Ordovician Fernvale Limestone averaged $2.65 \mathrm{~g} / \mathrm{cm}^{3}$ in density. Considering these measurements and the relative proportions of the rock types, a reasonable estimate of the density of the entire Arkansas Ozark Paleozoic section would be on the order of $2.70 \mathrm{~g} / \mathrm{cm}^{3}$.

Precambrian basement of the Arkansas Ozarks includes both igneous and metamorphic rocks. In the northeast part of the region, gravity and magnetic measurements suggest that basement-rocks are quite variable in composition and are oriented along northwest-trending structures. It may be that this area is underlain by rocks classified as "older" crustal terrane to the north (Kisvarsanyi, 1974). This classification includes mesozonal to katazonal granite, gneiss, and schist that have been dated at 1,520 m.y. (Muehlberger and others, 1966). These rocks are oriented along prominent and persistent northwest lineaments. This terrane has in turn been intruded by mafic plutonic rocks that range in age from 1,270 to 1,500 m.y. (Muehlberger and others, 1966).

Precambrian basement in west-central Arkansas may well be granite and acidic volcanic rocks associated with the St. Francois terrane in Missouri, which is shown to extend into northwest Arkansas (Kisvarsanyi, 1974). These rocks have an age of about 1,400 m.y. (Bickford and others, 1981). A circular $+23 \mathrm{mGal}$ anomaly in extreme northwest Arkansas is probably due to a mafic intrusion in the Precambrian terrane. However, in this area drill holes have not penetrated basement and 
TABLE 2.-Physical properties of units used in gravity and magnetic models

[M, measured; ES, density estimated from seismic velocity; E, estimated by comparison with rocks of similar composition]

\begin{tabular}{|c|c|c|c|c|c|}
\hline $\begin{array}{l}\text { Rock } \\
\text { type }\end{array}$ & Region & Type & $\begin{array}{l}\text { Density } \\
\left(\mathrm{g} / \mathrm{cm}^{3}\right)\end{array}$ & $\begin{array}{c}\text { Magnetic } \\
\text { susceptibility } \\
\text { (cgs } \times 10^{-6} \text { ) }\end{array}$ & $\begin{array}{c}P \text {-wave velocity } \\
(\mathrm{km} / \mathrm{s})\end{array}$ \\
\hline \multirow{4}{*}{ 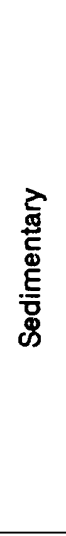 } & 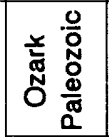 & $\begin{array}{c}\text { Dolomite } \\
\text { Limestone } \\
\text { Sandstone }\end{array}$ & $\begin{array}{c}2.74 \mathrm{M}^{(1)} \\
2.65 \mathrm{M}^{(1)} \text { Avg. } 2.7 \\
2.3 \text { to } 2.6 \mathrm{E}\end{array}$ & $\approx 0$ & $4.7^{(2)}$ \\
\hline & 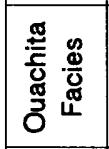 & $\begin{array}{l}\text { Lower - Shale } \\
\text { Sandstone } \\
\text { Upper- Shale } \\
\text { Sandstone }\end{array}$ & $\begin{array}{c}2.61 \mathrm{M}, \mathrm{E}^{(3,4)} \\
2.70 \mathrm{E}\end{array}$ & $\approx 0$ & Unknown \\
\hline & 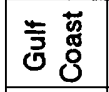 & & $\begin{array}{c}2.0 \text { to } 2.53 \mathrm{M}^{(3)} \\
\text { Avg. } 2.3^{(5)}\end{array}$ & 0 to 100 & \\
\hline & 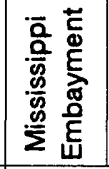 & & $2.3 \mathrm{E}^{(6)}$ & $\approx 0$ & $2.2-5.0^{(5)}$ \\
\hline \multirow{4}{*}{$\begin{array}{l}\stackrel{0}{0} \\
\stackrel{8}{ \pm} \\
\underline{5}\end{array}$} & & Granitic & $2.65 \mathrm{M}^{(7)}$ & $\approx 800 \mathrm{M}^{(7)}$ & $6.0^{(12)}$ \\
\hline & & Syenite & $2.52 \mathrm{M}^{(4)}$ & 1,000 to $2,000 \mathrm{M}^{(4)}$ & \\
\hline & & Diabase & 2.8 to $2.9 \mathrm{M}^{(4,8)}$ & 250 to $8,500 M^{(4,8)}$ & \\
\hline & & Ultramafic & 3.1 to $3.14 \mathrm{M}^{(4,9)}$ & $\approx 25,000 \mathrm{E}$ & \\
\hline$\frac{\text { d }}{\stackrel{5}{\delta}}$ & & $\begin{array}{l}\text { Upper crust avg. } \\
\text { Lower crust avg. } \\
\text { Anomalous crust } \\
\text { Mantle }\end{array}$ & $\begin{array}{c}2.65 \text { to } 2.8 E S^{(2,10,11,12)} \\
3.0 E S^{(8,11,12)} \\
3.15 E S^{(2,12)} \\
3.3 E S^{(8,11)}\end{array}$ & $\begin{array}{l}1,000 E \\
\text { Below curie point } \\
\text { Geotherm. }\end{array}$ & $\begin{array}{c}6.2^{(10)} \text { to } 6.35^{(12)} \\
6.5 \text { to } 6.75^{(2,12)} \\
7.4^{(2,12)} \\
8.1^{(12)}\end{array}$ \\
\hline
\end{tabular}

\section{SOURCES OF DATA}

\author{
1. This study \\ 2. McCamy and Meyer (1966) \\ 3. Cordell (1977)
}

4. Malamphy and Vallely (1944)

5. Keller and Surbet (1975)

6. Warren and others (1966)
7. Mateker (1959)

8. Phelan (1969)

9. Erickson and Blade (1963)
10. Stewart (1968)

11. Ervin and McGinnis (1975)

12. Peters and others (1981) magnetic data are not available, so the depth to the top of the causative body is unknown. Paleozoic rocks over the anomaly are about $0.5 \mathrm{~km}$ thick and are relatively undisturbed. Therefore if this anomaly is caused by an intrusion, its top is at a level below the base of the sedimentary section, and the intrusion is probably Precambrian in age.

\section{GRAVITY ANOMALIES OF THE ARKANSAS OZARKS}

In the Ozarks the gravity field is characterized by large areas of differing Bouguer levels and smoothness. In the northeast part of the region the gravity field is quite variable, consisting of a number of "highs" and "lows" separated by steep gradients. These anomalies are oriented along strong northwest trends, and Bouguer values in this area average about $-10 \mathrm{mGal}$. In the west-central Arkansas Ozarks, the gravity field is smoother and at a lower level than that toward the northeast. Bouguer values here average about -40 to $-45 \mathrm{mGal}$, and distinct trends are absent. This region of reduced and rather nondescript gravity is roughly circular in outline and encompasses an area of some $20,000 \mathrm{~km}^{2}$. A strong north-south gradient separates these two gravity regions of the Ozarks.

If the Precambrian basement in the northeast Arkansas Ozarks is of the "older" crustal type noted previously, this suite of rocks could easily produce the observed variations in the Bouguer gravity field. Correlation is excellent between circular gravity and magnetic "highs" in this region, and these anomalies may be associated with the mafic intrusions mentioned. Gravity and magnetic ridges may occur over rocks of intermediate composition, and troughs may occur over relatively felsic rock of the "older" crustal terrane.

Bouguer anomalies in the west-central Arkansas Ozarks, being at a relatively reduced level and lacking any well-defined trends, may result from a combination of a thicker crustal section and a fairly uniform and lowdensity upper crustal section. The boundary between these two areas of the Ozarks is marked by a strong north-south gravity gradient. Relief in the Bouguer 
gravity across this trend is about $20 \mathrm{mGal}$, which occurs over a horizontal distance of about $35 \mathrm{~km}$. Folds or faults observed in the Paleozoic section do not correspond to this gravity trend. If this gravity trend represents the boundary between contrasting Precambrian basement rock types, the implication is that a Precambrian structure formed this boundary. At the top of the Precambrian complex, rocks east of this structure appear to be older and of a higher metamorphic grade than those to the west. This gravity feature may then reflect a tectonic element marking a boundary where the present basement east of the feature was uplifted during late Precambrian time. East of this implied structure the relatively low density uppermost crustal rocks would have been removed by erosion prior to Paleozoic deposition; to the west they may have been preserved.

\section{GRAVITY ANOMALIES AND FAULTING}

A subtle relation exists between mapped surface faults (Haley and others, 1976) and the Bouguer anomalies in the Arkansas Ozarks. Faults in this region generally have less than $200 \mathrm{~m}$ of vertical displacement (B.R. Haley, oral commun., 1977), which cannot account for the associated gravity anomalies even if reasonable but large density contrasts are assigned to the various rock units. This implies that faults observed at the surface are related to changes in basement lithology and for the most part may represent reactivation of older basement structures. The amount and type (horizontal and (or) vertical) of movement on these proposed Precambrian structures cannot be determimed from analysis of the gravity data but must have been sufficient to bring rocks of differing densities into juxtaposition.

Two distinct trends characterize the surface faulting within the Arkansas Ozarks, northeast and northwest. Northwest-trending structures are along the same strike as those observed to the north in Missouri. Hayes (1962) and Kisvarsanyi (1974) interpreted this surface trend as resulting from recurrence along Precambrian structural lineaments. In the western Arkansas Ozarks, a set of northeast-trending faults appears to be related to the Precambrian Spavinaw arch (Denison, 1966). In the eastern Arkansas Ozarks, northeast-trending structures and geophysical anomalies may be related to tectonic activity of the Reelfoot rift (Ervin and McGinnis, 1975) and related Mississippi Valley graben (Kane and others, 1979), which is discussed in the Mississippi embayment section of this report. The boundary between the Ozarks and Arkansas Valley section is marked by the Mulberry fault system. This is a complex series of easterly trending normal faults with a net displacement in excess of $0.75 \mathrm{~km}$ down to the south. Drilling for hydrocarbons in this region indicates that faulting occurred during deposition of the Middle Pennsylvanian Atoka Formation. This fault system is reflected in the Bouguer anomaly as a gravity ridge with superimposed circular "highs" along strike of the system. The sources of these anomalies are not evident from surface or drilling observations: they may result from deep-seated crustal features associated with formation of the system, or ancient features may have controlled the location of the system. The eastern limit of the Arkansas Ozarks is marked by the edge of the sediments of the Mississippi embayment, and is discussed in a later section.

\section{OUACHITA MOUNTAINS AND ARKANSAS VALLEY}

The Ouachita Mountains and Arkansas Valley physiographic sections represent related structural features formed on the North American craton during Paleozoic time. The Ouachita Mountains section is a positive element formed mainly as allochthonous imbricated thrust sheets resulting from a northwestsoutheast compressional stress field. The Arkansas Valley is a syntectonic foreland basin.

\section{STRATIGRAPHY}

Rocks exposed in the Ouachita Mountains range in age from Early Ordovician(?) to Pennsylvanian (Atokan). This sedimentary section can be placed into two sequences based on rock type and implied rates of sedimentation (fig. 1). The older of these sequences (Early Ordovician(?) to Devonian(?)) consists of a maximum of about $1,700 \mathrm{~m}$ of mainly thin bedded dark shale and limestone with mimor quartzose sandstone. The upper division comprises about 7,500 $\mathrm{m}$ of interbedded dark shale and sandstone of Late Devonian to Pennsylvanian age and includes a lower part of up to $300 \mathrm{~m}$ of novaculite, chert, siliceous shale, and locally volcanic tuff.

Variations in the implied rate of deposition, sedimentary structures, and rock type suggest these two sequences of rocks were deposited in radically different environments. Goldstein (1959) indicated that the sedimentary units exposed and penetrated by drill in the Ouachita structural belt record a double geosynclinal cycle. The earlier (Ordovician-Silurian) synclinal axis may have been farther to the south-southeast compared with the Mississippian-Pennsylvanian depositional trough. Cline and Shelburne (1959) suggested that Ouachita sediments of Ordovician-Silurian age were deposited in a deep, essentially starved trough, and increased tectonic activity in Late Mississippian-Early Pennsylvanian time resulted in a substantial deepening and sediment influx.

The Arkansas Valley section is a foreland basin of the Ouachita orogeny. Restored sedimentary thicknesses and seismic information (Nelson and others, 1982; Lillie 


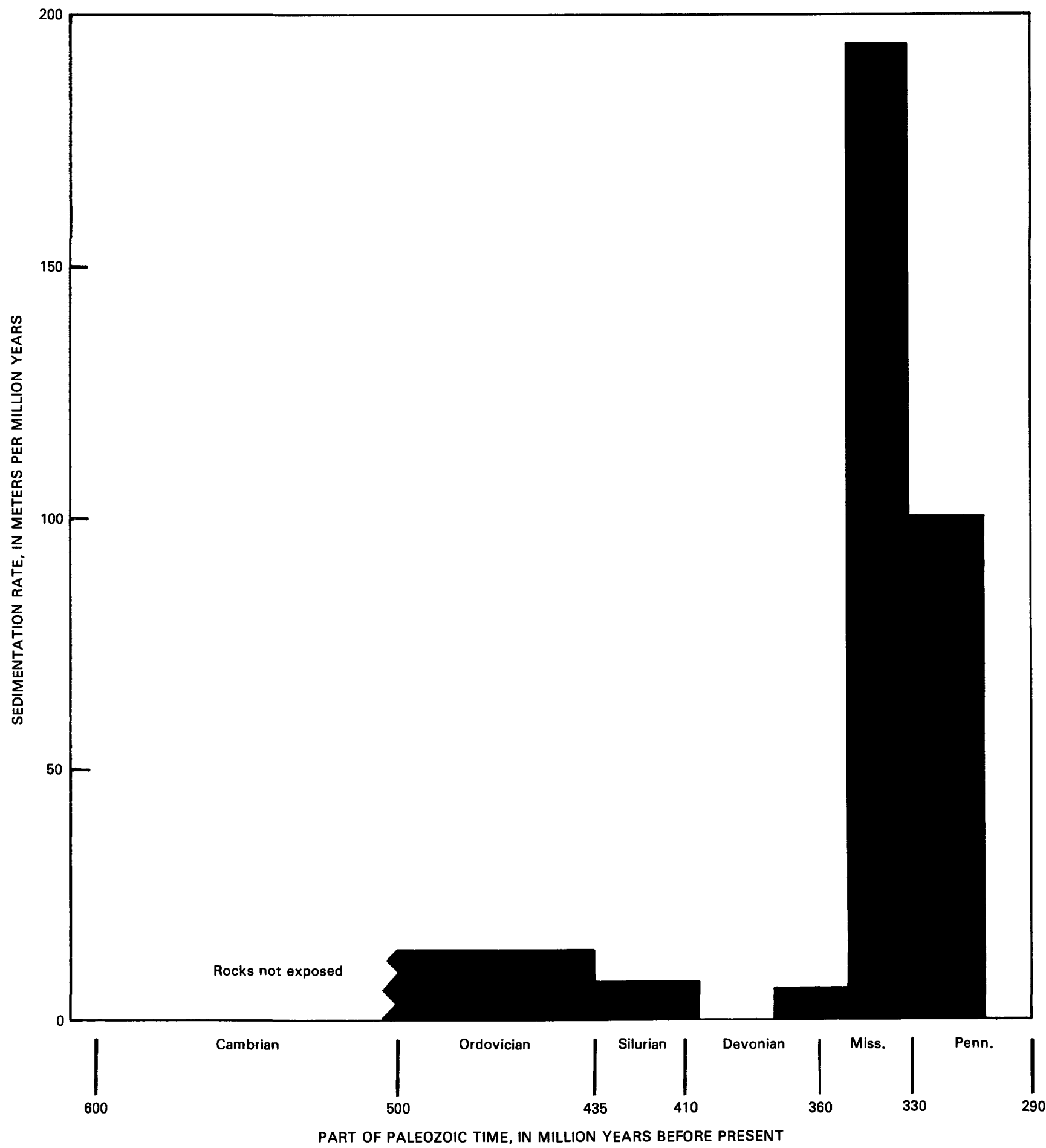

FIGURE 1.-Histogram of implied sedimentation rates for exposed Paleozoic rocks in the Ouachita Mountains.

and others, 1983) suggest that the sedimentary section in the basin may exceed $10 \mathrm{~km}$. Sedimentation here reached its peak in Atoka-Desmoinian time. Drilling and seismic data also suggest that early Paleozoic Ozark facies rock continues beneath at least the northern part of the Arkansas Valley and forms the sedimentary floor of the basin. The majority of the sedimentary rocks in the Arkansas Valley are sandstone and dark shale of the Pennsylvanian Atoka and Hartshorne Formations. 


\section{BOUGUER GRAVITY OF THE OUACHITA MOUNTAINS-ARKANSAS VALLEY}

The gravity field of the Ouachita Mountains and Arkansas Valley sections is characterized by one of the largest isolated gravity "lows" on the North American Continent (Lyons, 1961; Woollard and Joesting, 1964). The anomaly has an amplitude on the order of $100 \mathrm{mGal}$ and is elongate at a slight angle to the Ouachita structural belt in Oklahoma and Arkansas (fig. 2). This anomaly results from one or a combination of the following density variations: (1) increased thickness of relatively low density Paleozoic rocks, between the southern Ozark province and southern Ouachita Mountains, both by imbricate thrust faulting (in the Ouachitas) and original sedimentation; (2) changes in the lithology of the Precambrian basement complex; (3) increased crustal thickness; and (4) introduction of low-density units in the crust that have not been noted in wells or at the surface. A gravity and magnetic profile across this anomaly suggests that a combination of increased thickness of the sedimentary section along with downwarping of the crust-mantle boundary is the predominant cause of the gravity minimum (Lyons, 1961). This north-south profile is along the 95th parallel and intersects the center of the negative anomaly in eastern Oklahoma. Moho (Mohorovičic discontinuity) closure of at least $16 \mathrm{~km}$ is suggested at this location, which is near the central (north-south) part of the Ouachita Mountains. Farther east, in Arkansas, the maximum negative gravity values occur near the Ouachita Mountains-Arkansas Valley boundary (pl. 2), and the axis of the gravity "low" does not exactly parallel the trend of surface structural features. This supports the suggestion that density variations below the base of the sedimentary section are, at least in part, responsible for this gravity anomaly.

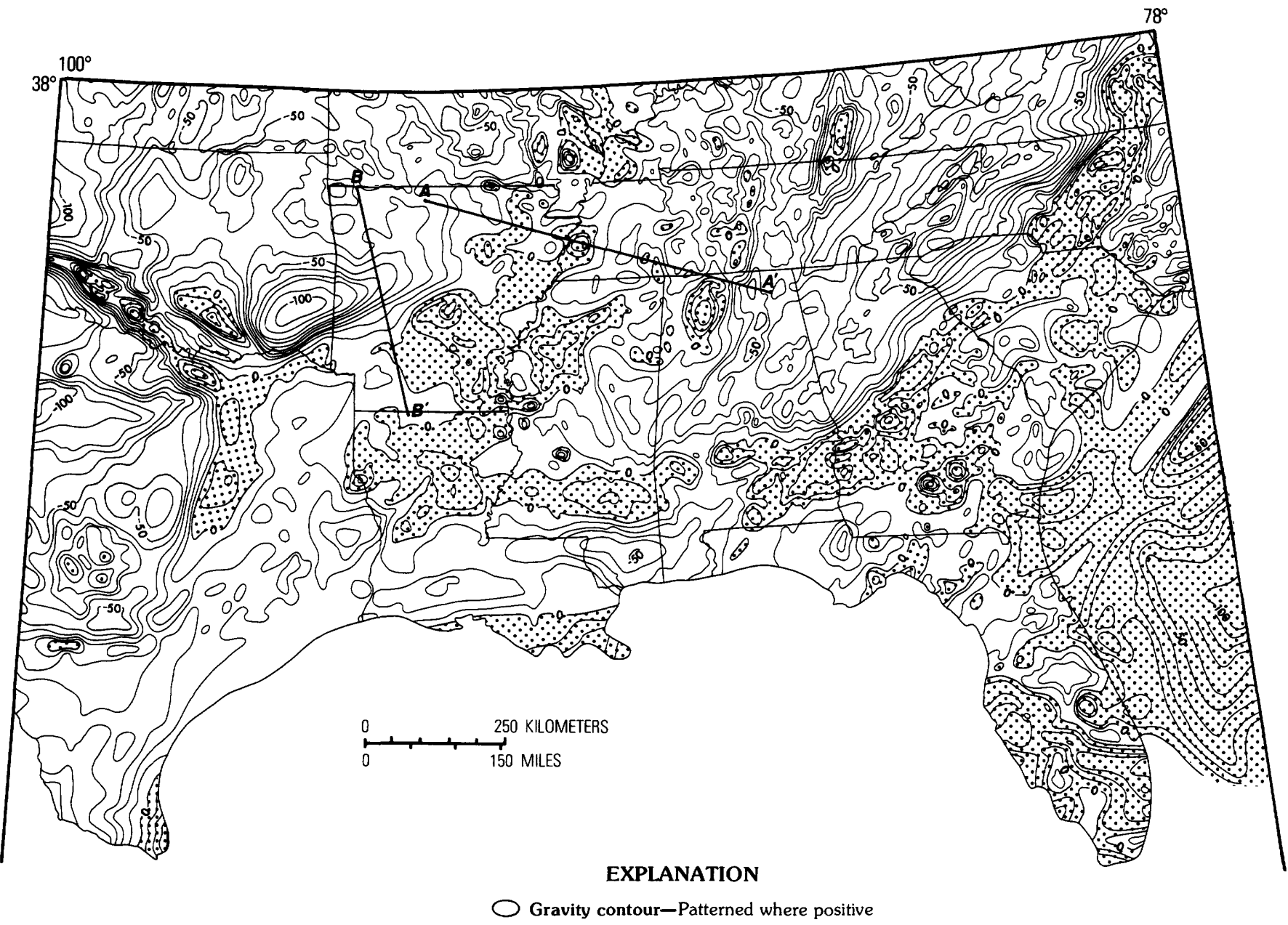

FIGURE 2.-Regional Bouguer gravity anomaly map of southeastern United States and adjacent portion of Atlantic Ocean. Areas of positive value patterned. Contour interval $10 \mathrm{mGal}$; reduction density $2.67 \mathrm{~g} / \mathrm{cm}^{3}$. Datum is $980.1188 \mathrm{gals}$. Modified from Woollard and Joesting (1964). $A-A^{\prime}$, location of profile of figure $5 ; B-B^{\prime}$, location of profile of figure 3. 
Figure 3 is a cross-sectional model constructed in order to approximate the corresponding observed gravity values (see fig. 2 for location of profile $B-B^{\prime}$ ). Very little is known about the densities and distributions of the crustal layers in this region, and therefore the model is quite speculative and offers only one of several possible solutions of the inverse geophysical problem. Due to the lack of information concerning the densities of the sedimentary rocks of the Arkoma basin and upper Ouachita facies and the nature of the Precambrian basement underlying these areas, no contrast in density was assumed between these units. If the sedimentary rocks are less dense than the underlying basement the effect on the model would be to lessen the vertical displacement shown in the lower and anomalous crustal layers and to change the geometry of the Arkansas Valley. The model therefore presents an estimation of the maximum amount of crustal deflection that could be expected in this area. South of the Ouachita Mountains the crustal thickness is extrapolated from Warren and others
(1966). As additional geophysical and deep-well information becomes available, this model will undoubtedly have to be altered. This gravity model is constructed to be compatible with the tectonic model presented in this report.

\section{TECTONIC MODEL FOR THE OUACHITA SYSTEM}

Many models of the tectonic history of the Ouachita system have been presented in an attempt to explain the observed features in the context of plate tectonic theory. The majority of these models suggested that the Ouachita structural belt (Flawn, 1959) coincides with, or is directly related to, a subduction complex that formed during the closing of the proto-Atlantic (Iapetus) ocean (Roeder, 1973; Morris, 1974; Briggs and Roeder, 1975; Graham and others, 1975; Wickham and others, 1976; Viele, 1979; Cebull and Shurbet, 1980; Walper, 1980). Other models suggested that the late Paleozoic

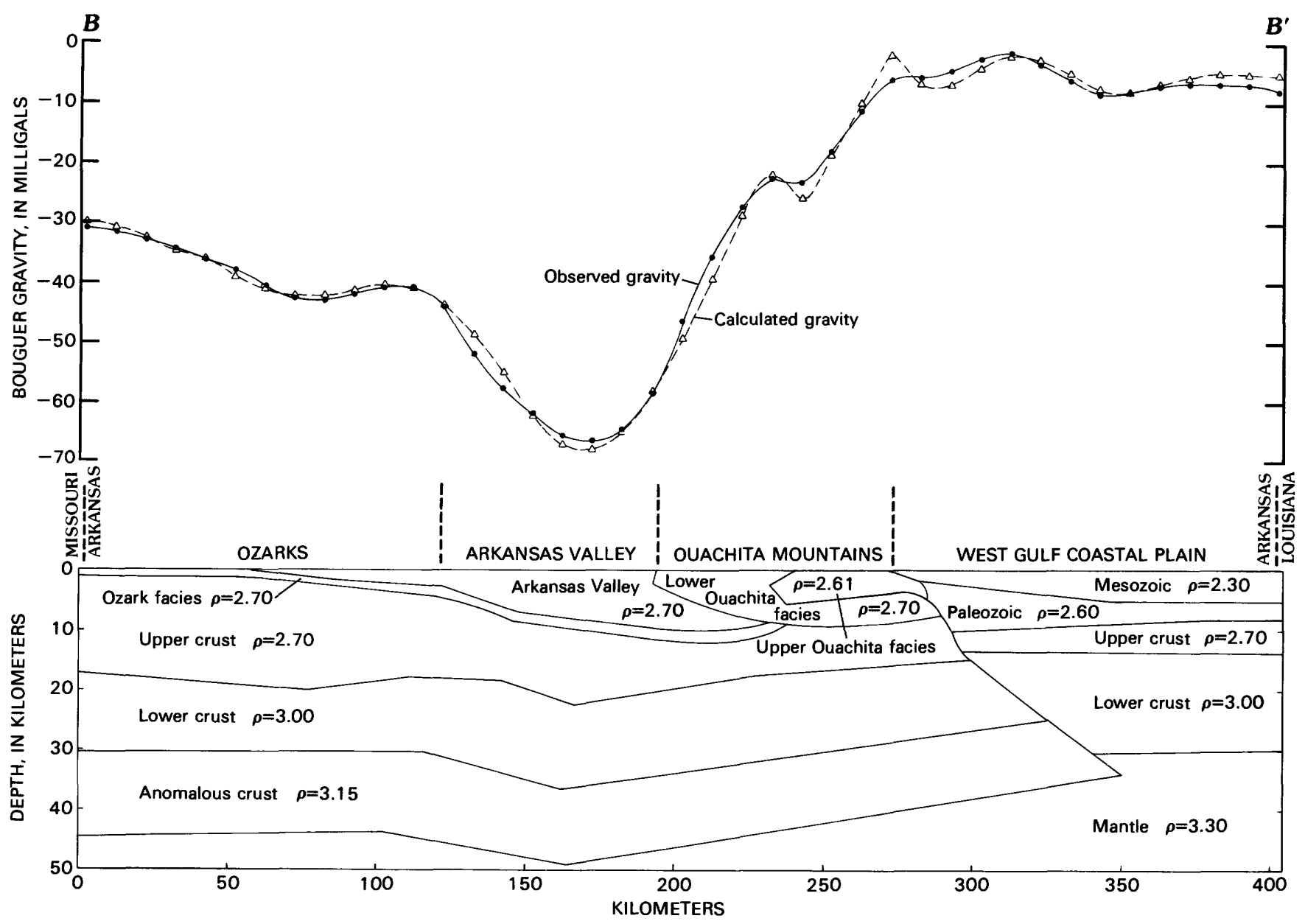

FIGURE 3.-Graph and cross section of two-dimensional gravity model in western Arkansas. (See fig. 2 for profile location.) Unit densities in grams per cubic centimeter. 
subduction occurred some distance to the south of the present Ouachita structural belt (Keller and Cebull, 1973; Pindell and Dewey, 1982). Eventually the Iapetus ocean was consumed (or nearly so) as the continents were juxtaposed during the Pangean configuration.

Some of the principal features (or lack thereof) that must be addressed by any tectonic model of the Ouachita structural belt are:

1. continental geometry during Late PennsylvanianPermian time

2. a southerly continental source area for some of the sediments of the Ouachita trough

3. nature of the crust gulfward of the Ouachita belt

4. apparent lack of late Paleozoic volcanic activity in the region

5. variability of geophysical anomalies in the Ouachita belt and Gulf Coastal Plain

6. structural features within the exposed Ouachita Mountains

7. grades and trends of metamorphism within the system

8. relation of post-Ouachita alkalic igneous rocks to the structural belt

The plate tectonic evolutional model presented here not only attempts to satisfy the above constraints but also incorporates observations presented in previous Ouachita reconstruction models. This model also adopts the suggestion that rifted continental blocks (microcontinents) were present along the eastern and southern margins of the North American craton prior to Pangea (Dietz and Holden, 1972; Thomas, 1977; White, 1980), and employs the concept of thin-skinned tectonics that has been applied to the Appalachian chain (Cook and others, 1979; Harris and Bayer, 1979).

Near the close of Precambrian time the proto-North American continent was joined with a landmass lying to the present southeast. An earlier formed, subparallel suture existed within the North American continent that corresponded to the Grenville front. The Grenville suture trended northeast across eastern Texas and eastern Arkansas. The Grenville and adjacent regions were emergent and of low relief (fig. 4A). Breakup of this supercontinent occurred near the beginning of the Cambrian Period with separation along the line shown in figure $4 B$. A passive continental margin was formed along the present eastern and southern edge of the proto-North American craton. Passive rifting, graben formation, and strike-slip faulting were common on and adjacent to the newly formed continental shelf. Relief in these grabens may have exceeded $4 \mathrm{~km}$, with widths that varied from less than one hundred to several hundred kilometers. The rifted Grenville blocks tipped and foundered but remained essentially fixed to the North American craton. Strike-slip faulting resulted from differential movements of these foundered blocks. In Arkansas, a major transform fault trending toward the present southeast marked the boundary between a rifted block and the craton. Another structure, possibly an extension of the ancestral Oklahoma aulacogen, was formed across central Louisiana and southern Mississippi. Localized igneous activity occurred within the grabens in Early Cambrian time. Failed arms of the major rifts occurred at sharp angles where major embayments were left in the stable craton.

Middle Cambrian to Late Ordovician was a time of relative quiescence in this region. Sedimentation rates were low in the troughs except near their cratonal ends. A system of through-going seaways was present, connecting open oceans around the periphery of the North American continent. Carbonate sedimentation occurred during the Ordovician in areas of the (now mostly filled) failed rifts and on adjacent platforms. Tectonic activity was low, although downwarping of the cratonic ends of the failed rifts (aulacogens) occurred as a result of sediment loading. Figure $4 B$ represents the physiography of the region during this period (Cambrian).

About $450 \mathrm{~m} . y$. ago the stress field changed from minor northwest-southeast tension to a major compression in the same direction, marking the beginning of the closing of the Iapetus ocean. Further tilting of the rifted Grenville blocks in response to this change in the stress field brought their southerly ends above sea level. On the North American side of the ocean, subduction of the Iapetus crust was occurring at the southeast edge of the Grenville blocks. Orogenic movement accompanied by acidic to intermediate volcanism was taking place in conjunction with this subduction. By the beginning of the Mississippian Period, clastic debris shed from the resulting mountains was deposited in the previously "starved" grabens at a rapid rate (fig. 4C). Northwest movement of the rifted block(s) south of the present Ouachita Mountains as a response to continued compression into Pennsylvanian time resulted in sediments of the troughs being thrust over cratonal platforms adjacent to the rift valleys to the north and west. Décollement zones were formed at the subhorizontal boundary between Precambrian crystalline basement and Paleozoic sedimentary rocks. The cratonic margin was depressed as a result of tectonic movement and thrust fault stacking of the now thick sediments of the troughs. Elongate mountain ridges, with relief on the order of $2 \mathrm{~km}$, formed ahead of the northwest-moving mobile blocks. Sedimentation shifted to deep basins formed on the downwarped cratonic margin. The mobile block south of the Ouachita system rotated about $10^{\circ}$ counterclockwise. The Oklahoma aulacogen and Arbuckle Mountains apparently represented a barrier to this rotation. Formation of the Arbuckle Mountains and 

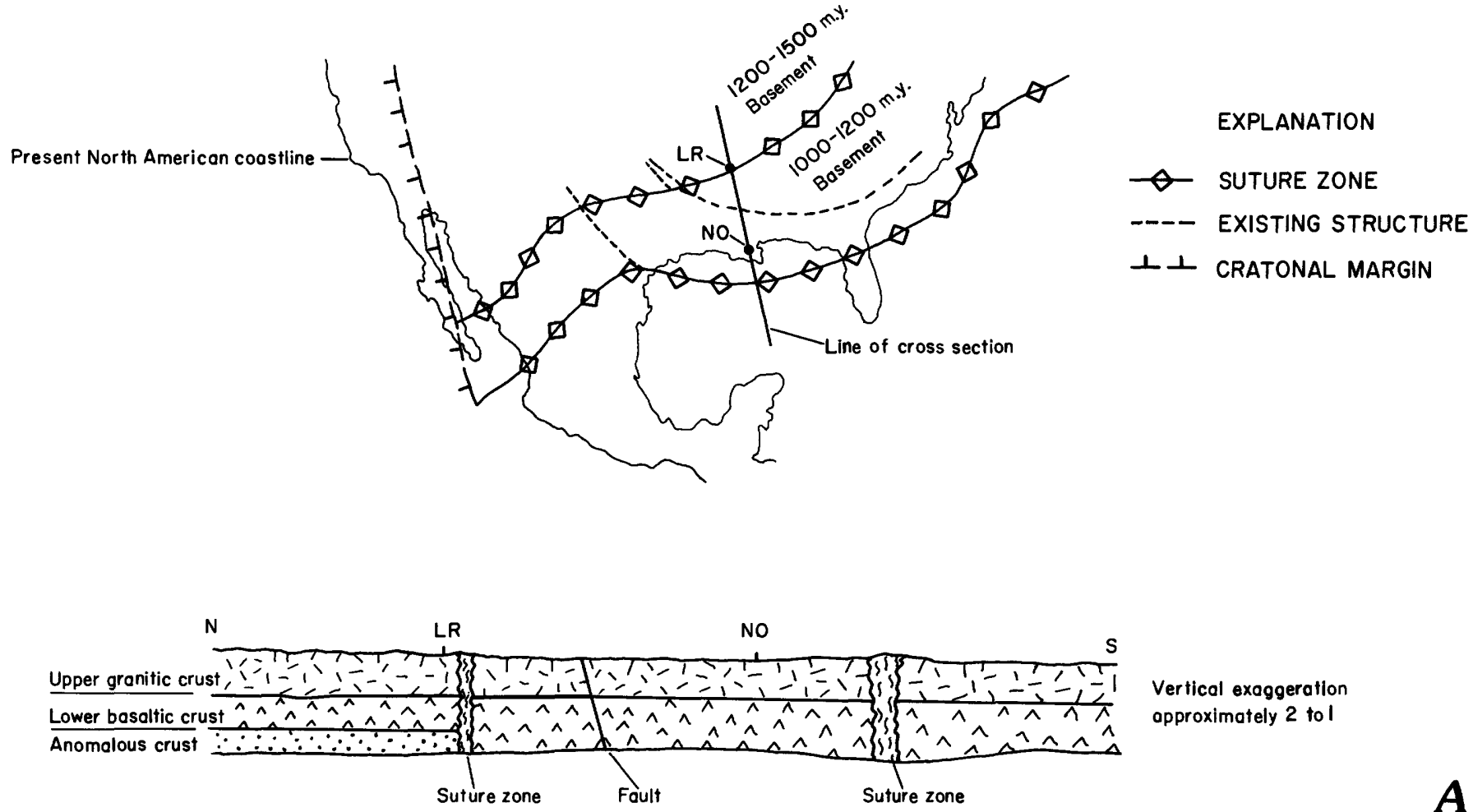

Vertical exaggeration approximately 2 to 1

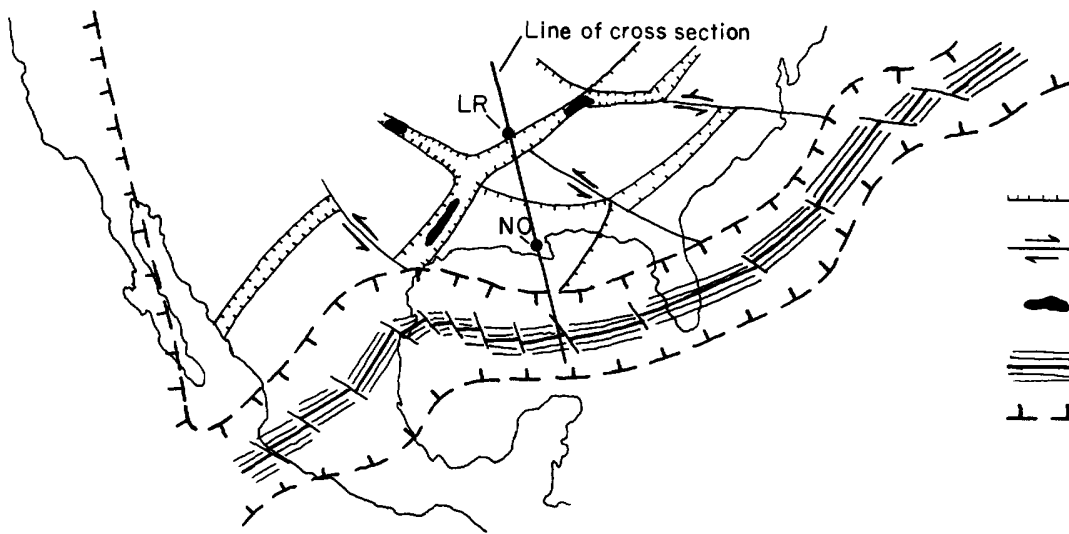

EXPLANATION

NORMAL FAULT

TRANSFORM FAULT

AREA OF VOLCANIC ACTIVITY

SPREADING CENTER

$\perp \perp$ CRATONAL MARGIN

N

LR
NO

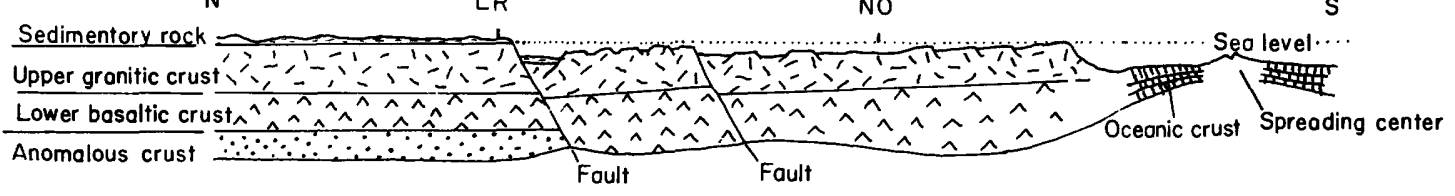

Vertical exaggeration approximately 2 to 1

FIgURE 4.-Maps and cross sections showing hypothetical tectonic evolution of southern North American continent from late Precambrian to present. Cross sections represent a distance of approximately $700 \mathrm{~km}$. LR, Little Rock, Ark.; NO, New Orleans, La. N, north; S, south (on cross sections). $A$, late Precambrian; $B$, Cambrian. 

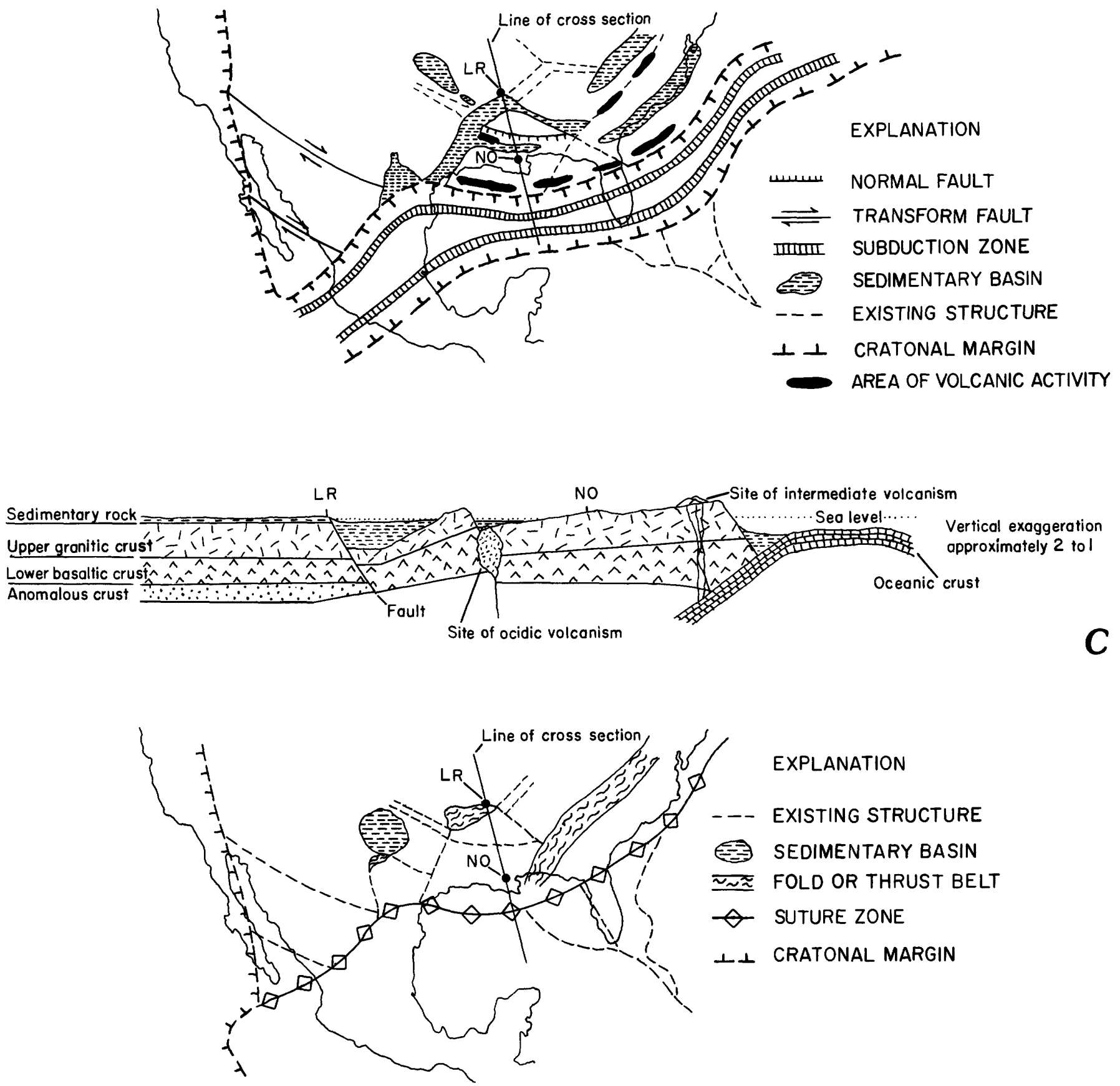

EXPLANATION

--- EXISTING STRUCTURE

$\Leftrightarrow$ SEDIMENTARY BASIN

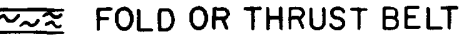

$\vartheta$ SUTURE ZONE

$\perp \perp$ CRATONAL MARGIN

N

NO

S

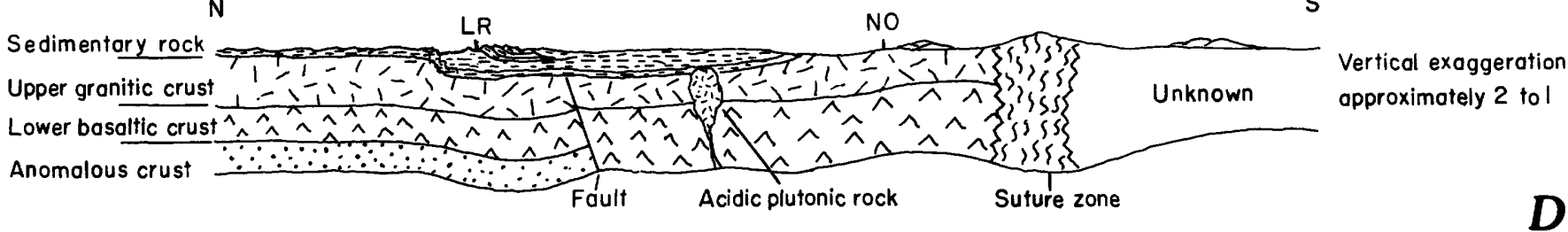

FIgURE 4-Continued.-Hypothetical tectonic evolution of southern North American continent. $C$, Mississippian; $D$, Permian. 

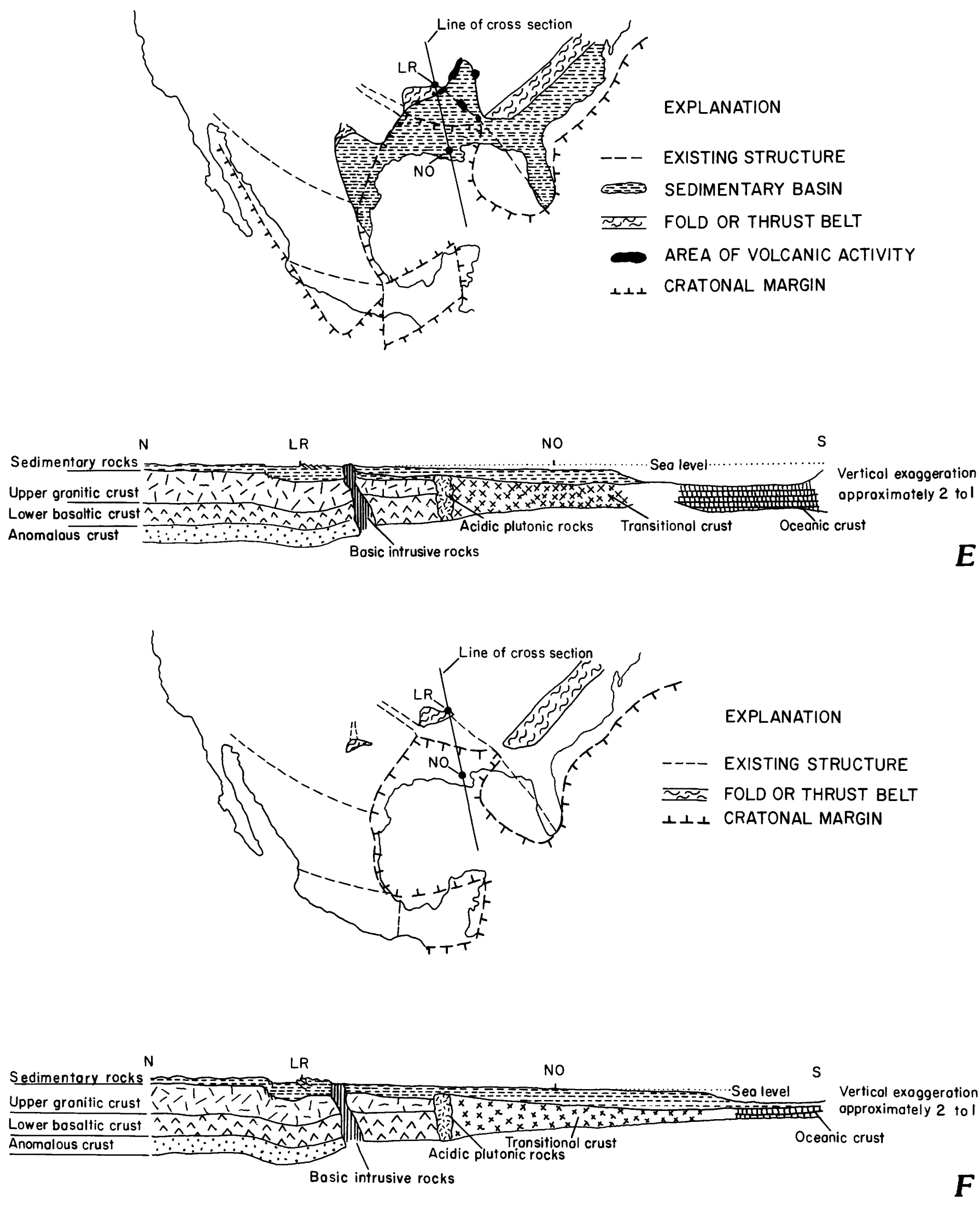

FIGURE 4-Continued.-Hypothetical tectonic evolution of southern North American continent. $E$, Cretaceous; $F$, Recent. 
Ardmore Basin occurred during the early stages of the orogenic event. Thrust faulting combined with left lateral strike-slip motion was occurring in east Texas. The Ouachita mobile block was bounded on the northeast by the earlier formed central Arkansas-southern Mississippi transform fault. Movement of this block was parallel to the strike of this fault, providing a right lateral offset. Rotation of the block about a pole located in its northerly part produced thrusting in a northeast direction in the vicinity of the Black Warrior Basin, Mississippi. Figure $4 D$ illustrates the physiography of the southeastern North American continent approximately $280 \mathrm{~m} . \mathrm{y}$. ago.

At the end of the Ouachita orogeny, the North and South American and African continents were juxtaposed and constituted a portion of the Pangean supercontinent. Continental geometry at this time is depicted in figure $4 D$. The Gulf of Mexico did not exist as we know it today and, for the most part, that region was above sea level.

Another period of relative quiescence existed in the area from about 275 to 200 m.y. ago. The land was emergent and the elevation of the Ouachita Mountains was $1-2 \mathrm{~km}$. Sediments shed from these mountains were transported to the west and southeast. About 200 m.y. ago the stress field again changed as the present North American and South American-African continents began to separate. Minor igneous activity near the end of the Triassic-Jurassic interval produced shallow dikes and sills south of the Ouachita structural belt. This diabasic event corresponded to rifting that eventually formed the Gulf of Mexico. This movement allowed reactivation of previously formed structures around the periphery of the forming gulf. Shallow restricted seas occupied areas corresponding to the boundaries of the previous blocks as they once again foundered in response to this separation. Thick sequences of evaporites accumulated in these seas during the Jurassic Period. The continental blocks that occupied the area between North and South America began to separate in Late Jurassic time and open ocean conditions replaced the earlier closed seas. The continental fragment immediately south of the Ouachita Mountains subsided but remained fixed to the craton. Large amounts of clastic sediment derived from the central part of the North American continent were deposited along the southern continental edge. Continuation of the Gulf of Mexico rifting combined with sediment loading resulted in downwarping of this area and marked the beginning of the Gulf Coast geosyncline. Reactivation of the Mississippi Valley graben and central ArkansasMississippi fault system occurred in response to tectonic activity in Early Cretaceous time. By the middle of Cretaceous time, the Mississippi embayment was a relatively low area and shallow seas advanced as far north as southern Illinois. Extensive alkalic volcanism occurred in conjunction with rift reactivation. Large bodies of fractionated basic magma migrated into the upper crust along existing faults within and adjacent to the Mississippi embayment. Figure $4 E$ is a representation of the regional physiography about $90 \mathrm{~m} . \mathrm{y}$. ago.

Downwarping of the Mississippi embayment and northern Gulf Coastal Plain continued until 40 m.y. ago, at which time this region was uplifted to its present elevations. Tectonic activity, however, has continued up to the present time and is noted by faulting along the New Madrid system, which corresponds to the ancient Mississippi Valley graben axis. The present-day physiography is depicted in figure $4 F$.

To address each constraint listed previously, this model proposes that:

1. North and South America were in juxtaposition during late Paleozoic time. The area between northern South America and the Ouachita Mountains was occupied by at least two rifted continental blocks (microcontinents). The configuration was similar to that proposed by White (1980) and Pindell and Dewey (1982).

2. Orogenic movement or tipping of the rifted blocks south of the Ouachita depositional trough prior to the Late Pennsylvanian-Permian Pangean configuration provided a continental sediment source.

3. Presently the crust in southern Arkansas and northern Louisiana is attenuated continental. In southeast Texas and southern Louisiana the crust is transitional between continental to the north and west and oceanic to the south, and is of Mesozoic age.

4. The apparent lack of Mississippian-Pennsylvanian volcanic activity within the Ouachita structural trend strongly suggests that the trend does not directly correspond to an ancient subduction complex.

5. The variability of major gravity anomalies associated with the Ouachita trend results from a combination of differing basement rock types from one part of the system to another, a late Precambrian or Early Cambrian rifting and magmatic event, differing styles of deformation during the Ouachita orogeny, and emplacement of Mesozoic igneous rocks along pre-Ouachita zones of weakness.

6. The major structural features of the Ouachita Mountains (folds and thrust faults) result from a northwest-southeast compressional stress field and process of thin-skinned tectonics. Sedimentary rocks of the Ouachita trough moved northwestward as much as $100 \mathrm{~km}$ along décollement 
zones formed at the top of the Precambrian basement.

7. Metamorphic facies in rocks of the Ouachita structural trend fall into three categories (Flawn, 1959, pl. 1): (1) incipient to low-grade metamorphism with local shearing or hydrothermal alteration, (2) incipient to weak metamorphism, and (3) lowgrade metamorphism with a strong shearing component. The first of these is found mainly in Cambrian through Devonian age rocks in the most intensely deformed parts of the Ouachita Mountains. Miser (1959) indicated that this metamorphism decreases away from the axis of maximum deformation and suggested that the metamorphic process involved both dynamic and burial effects. In Texas and northern Mexico the metamorphic grade of rocks of the Ouachita structural belt appears to change from relatively unaltered nearest the cratonal side of the belt through a zone of incipient to weak metamorphism to a zone of lowgrade metamorphism with a strong shearing component. Denison and others (1977) suggested two ages for the metamorphism observed on Ouachita facies rocks, Devonian and PennsylvanianPermian. In this proposed model the Devonian age would reflect initial movement of the rifted blocks and volcanic activity oceanward of the present Ouachita belt. The Pennsylvanian-Permian metamorphic imprint would represent the main orogenic episode of thrust faulting and folding of the rocks of the Ouachita trough. Maximum burial metamorphic alteration would have also occurred in Pennsylvanian time and would be most pronounced in the older, more deeply buried rocks of the Ouachita trough.

8. In this model, Mesozoic alkalic intrusive rocks in Arkansas occur along ancestral zones of weakness, which also controlled the location of the Ouachita system. This suite of igneous rocks ranges from kimberlite and peridotite to nepheline syenite. Plutonic rocks of these types are associated with major structural features within continental areas and are not common to subduction complexes. The occurrence of these types of rocks in and gulfward of the Ouachita structural belt, therefore, argues against suggestions that the belt represents the site of a late Paleozoic subduction complex.

\section{MISSISSIPPI EMBAYMENT}

The area referred to in this report as the Mississippi embayment is a part of the Mississippi Alluvial Plain physiographic section (Fenneman, 1946) and is outlined on plate 2. The Arkansas portion of the Mississippi embayment encompasses an area of approximately $40,000 \mathrm{~km}^{2}$. This region of very low relief is covered, for the most part, by deposits that are Quaternary to Holocene in age. Because of historic earthquake activity within the region, the embayment has received a great deal of geologic attention within the last 10 years.

\section{GEOLOGIC HISTORY}

During most of Paleozoic time the region of the Mississippi embayment was the site of a trough accumulating both carbonate and clastic sediments. This trough, as denoted by the top of the Precambrian surface, is a northeast-trending depression approximately $70 \mathrm{~km}$ wide with steeply dipping sides. Relief on the Precambrian surface is from 1.6 to $2.6 \mathrm{~km}$. This feature will be referred to here as the Mississippi Valley graben. The graben was nearly filled by Ordovician time, and downwarping continued as a result of sediment loading and (or) tectonic forces. Accumulation of sediments in the deeper parts of the trough exceeded $4 \mathrm{~km}$. Toward the close of the Paleozoic and into the early Mesozoic Era, stresses apparently unrelated to the graben resulted in uplift and erosion of part of the sedimentary section and formation of the Pascola arch near the northern end of the embayment. These forces were probably related to the Appalachian and Ouachita orogenies.

Downwarping which formed the present Mississippi embayment began in Early to middle Cretaceous time, and sedimentation continued until the Eocene. This Cretaceous and Tertiary fill consists mainly of poorly consolidated to unconsolidated sand, silt, and clay, which have a maximum thickness in excess of $1.5 \mathrm{~km}$ in southeast Arkansas. After the close of this sedimentation, the embayment underwent a mild uplift to its present position; its elevations range from 30 to $100 \mathrm{~m}$.

The middle part of the Cretaceous was also a time of major alkalic igneous activity both within the embayment and adjacent to it. Although these igneous bodies are not exposed in the embayment, many have been penetrated by drill (pl. 2). Rocks emplaced during this period of magmatism cover a wide range in composition from nepheline syenite to mica peridotite, lamprophyre, and kimberlite (for example, Moody, 1949; Caplan, 1954; Gordon and others, 1958; Erickson and Blade, 1963). In the northern Mississippi embayment intrusions were along border faults of the Mississippi Valley graben (Smith, 1974; Hildenbrand and others, 1977, 1982; Hendricks and Glick, 1979; Glick, 1982). In the southern part of the embayment and to the southeast, Cretaceous igneous activity occurred along a line that reaches from Little Rock, Ark., across northeast 
Louisiana, central Mississippi, and probably into southern Alabama (fig. 2). The Murfreesboro kimberlite in southwest Arkansas is probably a comagmatic feature, as it is also Cretaceous in age (Miser and Ross, 1925) and lies along the southwest projection of the northwest Mississippi Valley graben border fault. The correspondence of alkalic igneous activity to the geometry of the graben suggests reactivation of rifting during this period of time (Burke and Dewey, 1973).

\section{TECTONIC HISTORY OF THE MISSISSIPPI EMBAYMENT}

The Mississippi embayment region has a long and complex tectonic history. The earliest event that can be documented with any certainty is a late Precambrian or Early Cambrian rifting phase. The mechanism by which rifting occurred, however, is unclear. Two basic models of formation have been proposed: (1) rifting resulting from tensional forces caused by crustal doming over an intrusion of anomalous mantle material into the lower crust, that is, active rifting (Ervin and McGinnis, 1975); or (2) rifting and graben formation resulting from tensional stress by brittle fracture and shear along a boundary or suture between contrasting basement rock types, or passive rifting (Hildenbrand and others, 1982). Initial rifting was accompanied by intrusion of minor amounts of basic to ultrabasic material along the rift axis. These intrusive bodies are northeast of the present study area and have been discussed by Hildenbrand and others (1982).

\section{GRAVITY MODELING}

In a two-dimensional gravity model by Ervin and McGinnis (1975), the Mississippi Valley graben is located roughly parallel to the strike of the Mississippi embayment. Interpretation of seismic profiles by McCamy and Meyer (1966) and Stewart (1968) was used for control of the various velocity-density units for this model (table 2). The profile of Stewart (1968) was obtained in central Missouri and indicates a standard continental crustal structure with a depth to the Moho of $40 \mathrm{~km}$. Interpretation of a northeast refraction line recorded along the northwest edge of the Mississippi Valley graben by McCamy and Meyer (1966) suggests that a 15-kın-thick mass of anomalous crustal material underlies the location of this profile. (See pl. 2 for profile location.) Peters and others (1981) reported on seismic refraction studies carried out in the northern Mississippi embayment and presented a line perpendicular to the McCamy and Meyer (1966) profile that intersects at lat $35^{\circ} 50^{\prime} \mathrm{N}$. long $90^{\circ} 50^{\prime}$ W. (pl. 2). Their interpretation also suggested that anomalous crustal material underlies this part of the embayment but is approximately $10 \mathrm{~km}$ thick and that the Moho is at a depth of $34 \mathrm{~km}$. The discrepancy between the two seismic models probably results from the presence of a number of basic intrusions along the borders of the embayment. Seismic lines of sufficient length to record mantle refractions would have to cross major intrusive bodies, which could provide a basis for the variation in the refraction interpretation.

The gravity of the Mississippi embayment is characterized by relatively high Bouguer values (Lyons, 1961; Woollard and Joesting, 1964; Cordell, 1977). In order to account for this gravity "high," Ervin and McGinnis (1975) proposed that beneath the embayment the anomalous $(7.4 \mathrm{~km} / \mathrm{s})$ crustal layer of McCamy and Meyer (1966) increases in thickness and that lower crustal rocks $(V p=6.5 \mathrm{~km} / \mathrm{s})$ are in direct contact with the base of the Paleozoic sedimentary section. The $7.3-7.4 \mathrm{~km} / \mathrm{s}$ unit is supposed to represent emplacement of anomalous mantle material in late Precambrian time, which resulted in formation of the Reelfoot rift and Mississippi Valley graben. Therefore, this model would require that this layer be unique to the embayment and die out away from the rift. Healy and Warren (1969, p. 210) indicated, however, that a seismic layer at the base of the crust with a velocity that ranges from 7.1 to $7.4 \mathrm{~km} / \mathrm{s}$ is present in all of their profiles recorded in Arkansas, southern Missouri, eastern Oklahoma, and the Texas panhandle. This layer thickens to as much as $20 \mathrm{~km}$ in eastern Oklahoma and does not appear to be confined to the Mississippi embayment. East of the Mississippi River this layer is not noted, which supports the suggestion by Hildenbrand and others (1982) that the Reelfoot rift formed along a suture separating crustal blocks of differing lithology and age.

The suggestion that lower crustal rocks are in contact with Paleozoic sedimentary units at a depth of about $4 \mathrm{~km}$ in the embayment is not supported by recent magnetic and drill hole information. The magnetic field over the Mississippi Valley graben was shown by Hildenbrand and others (1981) and Kane and others (1981) to be a pronounced "low." If lower crustal rocks (basaltic composition) having a magnetic susceptibility on the order of $1 \times 10^{-3} \mathrm{cgs}$ (centimeter gram second) units or more were present at a depth of $4 \mathrm{~km}$ beneath the embayment, and adjacent regions had a "typical" continental granitic upper crust, the magnetic field would be expected to be higher and (or) more variable than is observed in this area. In addition, a drill hole within the embayment (pl. 2) encountered granite of Precambrian age (Howard Schwalb, written commun., 1979, in Hildenbrand and others, 1982) at a depth of $4.3 \mathrm{~km}$, as predicted by estimates derived from magnetic measurements (Hildenbrand and others, 1980). 
Based on recent drill-hole and geophysical information pertaining to the nature of the Precambrian basement complex in the Mississippi embayment, as well as the suggestion of rift formation by Hildenbrand and others (1982), an alternate gravity model for the upper Mississippi embayment is presented (fig. 5). This profile is located identically to that of Ervin and McGinnis (1975) and shows another mass distribution that would result in the same Bouguer anomaly pattern. An exact match of observed and calculated gravity was not attempted because: (1) the method used to calculate the theoretical anomaly is two-dimensional and assumes that the density bodies are continuous perpendicular to the strike of the profile; and (2) the exact densities and depths of the bodies are not known. The results do, however, indicate that the implied density distribution, with minor alterations, is one possible solution to the observed gravity field.
OUACHITA STRUCTURE AT DEPTH IN THE MISSISSIPPI EMBAYMENT

In Arkansas, the boundary between the Ouachita Mountains and Arkansas Valley physiographic sections (pl. 2) is the northern limit of the major thrust faulting associated with Ouachita orogeny. Ouachita facies rocks are not exposed in the Mississippi embayment, but the continuation of the structural front has been shown as trending toward the southeast in the subsurface (Caplan, 1954; King, 1969) to either join with or cross the Appalachian chain in east-central Mississippi.

The regional gravity anomaly (fig. 2) suggests the possibility of a different style of deformation along this buried Ouachita extension compared with that exposed in the Ouachita Mountains. In western Arkansas and southeastern Oklahoma, the Ouachita Mountains and Arkoma basin are characterized by the large elliptical gravity minimum centered in eastern Oklahoma.

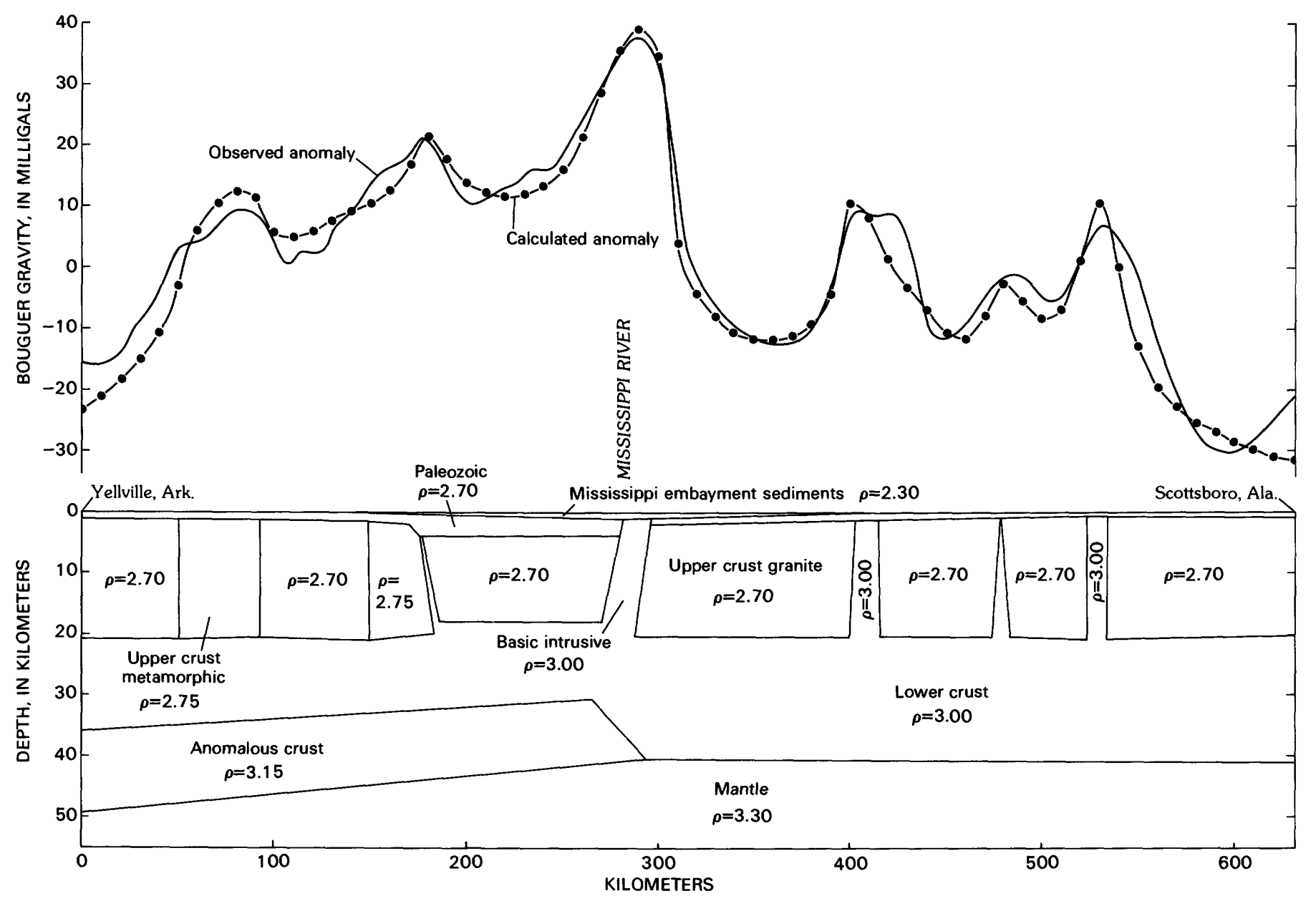

FIGURE 5.-Graph and cross section showing two-dimensional gravity model from Yellville, Ark., to Scottsboro, Ala. (See fig. 2 for profile location $A-A^{\prime}$.) Rho ( $\left.\rho\right)$, density in grams per cubic centimeter. 
Beneath the sediments of the Mississippi embayment and Gulf Coastal Plain, Ouachita facies rocks have been encountered in wells along a narrow band from Little Rock, Ark., to east-central Mississippi and have been included in the western Mississippi slate belt and central Mississippi deformed belt (Thomas, 1977). The gravity anomaly in the area of the suggested Ouachita frontal extension varies from lows with amplitudes of less than $20 \mathrm{mGal}$ to highs of more than $20 \mathrm{mGal}$. This is im marked contrast to the large gravity minimum associated with the exposed portion of the Ouachita system.

The allochthonous nature of the exposed Ouachita orogenic belt has been clearly demonstrated (Hendricks, 1959; Flawn and others, 1961). The increased thickness of the sedimentary section in the Arkoma basin combimed with stacking of the Ouachita facies section by imbricate thrust faulting would account, im part, for the gravity minimum observed in the exposed Ouachita orogenic belt (Lyons, 1961; Nicholas and Rozendal, 1975). Similar gravity "lows" are associated with the southwestern buried extension of the Ouachita system in Texas, although they are somewhat smaller in amplitude (up to $-60 \mathrm{mGal}$ ).

If thrust faulting occurred during the Ouachita orogeny along the entire Ouachita system from east-central Mississippi to south-central Texas, a complex history of movement would be imdicated because of the relative direction of displacements. Northward thrusting of Ouachita facies rocks is clearly demonstrated in western Arkansas, and movement with a westerly component is indicated in eastern Texas. These two segments of the system could be produced by a single northwest compressional stress field. If so, the thrustimg must have been accompanied by strike-slip movement; in Arkansas the displacement would be right lateral and im eastern Texas it would be left lateral. The Black Warrior Basin, Miss., lies on the cratonic side of the junction of the Ouachita and Appalachian trends. Thrust-faulted Ouachita facies rocks have been suggested as forming the southwest margin of this basin (Mellen, 1953; Vernon, 1971). The geometry of this area would require a northeast movement of the Ouachita orogenic block. All this thrust faulting is assigned to the Ouachita orogeny (Middle Pennsylvanian through Permian). Several possibilities exist to explain the preceding observations: 1. The stress field changed during the Ouachita orogeny from east-west compression, forming the east Texas portion of the system; to north-south compression, forming the Arkansas portion of the system; to northeast-southwest compression, resulting in thrusting along the southwest margin of the Black Warrior Basin. These events could have also occurred in reverse order.
2. Three or more blocks constituted the mobile part of the orogenic belt, each moving in the direction necessary to result in the observed thrusting.

3. A northwest movement and counterclockwise rotation of a single mobile block occurred south of the present structural belt.

Which, if any, of the above occurred during the Ouachita orogeny cannot be unequivocally stated with information currently available. Each of the three models has certain drawbacks. In the first, a rotation of the stress field of nearly $180^{\circ}$ during Ouachita orogenic time may not be unrealistic but would place serious restrictions on adjacent tectonic elements, none of which have features that would suggest this type of variation. Also, if movement of the orogenic block varied from west to north to northeast or vice-versa, parts of the system would be under tensional stress with compression in opposing areas. Structural features suggesting this type of stress field have not been reported. The second model has the same restrictions as the first with the additional hindrance of requiring a spreading center located somewhere in present-day Louisiana during the Ouachita orogeny. The continuity of the Ouachita system argues against this type of movement. The third model is the most attractive, as it would satisfy the implied stress fields and observed geophysical anomalies along the part of the Ouachita belt im question.

\section{WEST GULF COASTAL PLAIN}

\section{STRATIGRAPHY}

An area of approximately $35,000 \mathrm{~km}^{2}$ in southern Arkansas lies im the West Gulf Coastal Plain section of the Coastal Plain province; it is a region of low rolling hills with maximum relief on the order of $100 \mathrm{~m}$. Surface rocks of the region range in age from Early Cretaceous to Eocene and generally dip and imcrease in thickness toward the south. A thick southerly-opening wedge of Jurassic sandstone, siltstone, limestone, and evaporite underlies the Cretaceous and younger formations. Mesozoic formations, for the most part, thin to a feather edge at their northernmost limits and thicken to a total of about $3 \mathrm{~km}$ along the Arkansas-Louisiana border. Drill holes im southern Arkansas and northern Louisiana mdicate that these rocks overlie a sedimentary unit of relatively undeformed, unmetamorphosed, post-Ouachita-age Paleozoic rocks (Vernon, 1971). A folded Paleozoic sedimentary sequence of unknown thickness has been noted in a few wells in this region underlying the undeformed, unmetamorphosed Paleozoic rock. These rocks were termed "Ouachita 
facies" by Vernon (1971), who also indicated that gulfward of the Ouachita tectonic belt, as mapped by Flawn and others (1961), metamorphism decreases or is nonexistent compared to the low-grade facies observed in the tectonic belt. Diabase dikes and sills have been encountered in many wells in the southern part of this region intruding Jurassic and older formations. Near the West Gulf Coastal Plain-Mississippi embayment boundary, alkalic igneous intrusions have also been noted in drill holes and generally correspond with large circular gravity anomalies (pls. 1 and 2).

\section{GRAVITY PATTERNS}

South of the Ouachita structural trend the East and West Gulf Coastal Plain and Mississippi Alluvial Plain can be separated into two regions on the basis of the gravity field. Bouguer values in northern Louisiana, Arkansas, central Mississippi, Alabama, and northeast Texas average approximately $0 \mathrm{mGal}$; in southeast Texas and southern Louisiana, $-20 \mathrm{mGal}$ is a representative value (fig. 2). The division between the two regions is quite sharp and occurs along a line running east-west across southern Mississippi and central Louisiana to the Texas border in the vicinity of the Sabine uplift (lat $32^{\circ} \mathrm{N}$.), then trending toward the northwest to merge with the gravity anomaly associated with the Oklahoma aulacogen. This difference is possibly due to a thicker post-Paleozoic section in southeast Texas and just landward of the present gulf shoreline as opposed to the remaimder of the Gulf Coastal Plain. (See, for example, Vernon, 1971, fig. 3.) If sedimentation kept pace with, or aided in, downwarping of the Gulf Coast geosyncline, as appears to be the case (Imlay, 1949), the implication is that subsidence in southeast Texas and along the present gulf shoreline was at a greater rate than or began slightly before subsidence in the rest of the geosyncline. A difference of 1.5 to $2 \mathrm{~km}$ in the thickness of the synclinal sediments could provide this difference of approximately $20 \mathrm{mGal}$.

In the model proposed here, the region of the present Gulf Coast geosyncline was occupied by two fragmented continental blocks during the Pangean configuration. The geometry of the region was similar to that proposed by White (1980). Rifting between North and South America that began in Triassic time allowed separation of these two blocks along the boundaries shown in figure $4 D$. The smaller northern fragment foundered but remamed fixed to the North American continent; however, the southern block was rifted and rotated approximately $27^{\circ}$ about a pole located presently at lat $30^{\circ} \mathrm{N}$., long $70^{\circ} \mathrm{W}$. This block is now represented by the Yucatan region of Central America and
Mexico (White, 1980). This model would require a rift between these two blocks with Mesozoic oceanic crust filling the space left as separation progressed. As noted by Keller and Shurbet (1975), the crust between the Ouachita structural trend and the present Texas Gulf shoreline is best described as transitional between cratonic to the northwest and oceanic in the Gulf of Mexico. Relatively high Bouguer values in the Coastal Plain of Arkansas, northern Louisiana, and central Mississippi result from a combination of a thinner Mesozoic-Cenozoic sedimentary section, the presence of a large amount of post-Ouachita basic igneous intrusive rock, and possibly the occurrence of pre-Ouachita felsic to intermediate intrusive bodies. In the proposed model the locations of these intrusive bodies are controlled by Ouachita and pre-Ouachita structural elements.

In Arkansas the gravity signature of this section, other than the "bulls-eye" anomalies (pls. 1 and 2), is characterized by rather broad low-amplitude highs and lows separated by bands of relatively steep gradients. These anomalies cannot be directly related to structural features observed in the post-Paleozoic section and probably reflect structural deformation and lithologic variations of the Ouachita, pre-Ouachita Paleozoic, and (if present) Precambrian basement. Local gravity anomalies may also result from the presence of diabasic intrusions. Of the diabasic intrusions encountered to 1978, many occur in the areas characterized by steep gravity gradients and localized gravity "highs" (pl. 2). Steep gradients may, in part, represent the margins of sills, which could be controlled by pre-intrusion faults.

A fundamental question regarding the subsurface of the entire Gulf Coastal Plain is the nature of the crust below the Paleozoic sedimentary rocks. Two basic schools of thought exist on this subject: (1) The Ouachita tectonic belt represents the edge of the Paleozoic North American craton, and the Gulf Coastal Plain rests on oceanic-type crust. (2) The crust in this region is continental and represents a foundered and attenuated continental fragment formed during a late Precambrian or Early Cambrian rifting phase.

\section{GRAVITY ANOMALIES RESULTING FROM PHANEROZOIC IGNEOUS ACTIVITY}

Igneous intrusive bodies (area greater than $1 \mathrm{~km}^{2}$ ) crop out in three locations within the State of Arkansas: peridotite in Pike County (kimberlite at Murfreesboro), Magnet Cove-Potash Sulphur Springs, and at Little Rock (Little Rock Complex) (Gordon and others, 1958) (pl. 2). In addition, numerous dikes, sills, and small pipes are common in the eastern Ouachita Mountains and Arkansas Valley but do not produce 
gravity anomalies that are obvious at the scale of the present survey. Although all exposed igneous rocks occupy less than 1 percent of the surface area of the State (Stone and Sterling, 1964), drilling in southern and eastern Arkansas (pl. 2) suggests that igneous activity was extensive south of the Ouachita Mountains during the Mesozoic Era (Moody, 1949; Caplan, 1954). At least two periods of igneous activity are suggested in this region: a Triassic(?)-Jurassic diabasic event that produced dikes and sills, mainly in southwestern Arkansas, and a widespread Cretaceous alkalic event that resulted in the formation of igneous bodies, of variable composition, that range in size from narrow dikes to batholiths as much as $700 \mathrm{~km}^{2}$ in subsurface area.

Except for the small pipes and dikes of the Ouachita Mountains, the inajority of both outcropping and subsurface igneous bodies have pronounced corresponding gravity and magnetic anomalies. Diabasic intrusions in southern and southwestern Arkansas penetrated in wells (pl. 2), however, do not produce strong isolated anomalies that can be directly related to the igneous rocks. This apparent lack of definitive gravity anomalies can be explained two ways: (1) the dikes are too small (narrow) to be detected by the present survey and the sills are too thin (a 100-m-thick sill intruded into the Mesozoic sedimentary section would produce only a 1-2 $\mathrm{mGal}$ anomaly); and (or) (2) sills are laterally extensive and only the edges would be distinguishable using gravitational inethods. Seven wells in this region of the Arkansas Gulf Coastal Plain appear to be associated with a region of increased gravity gradient that may represent the borders of relatively thick sills (approximately $300 \mathrm{~m}$ ). When aerolnagnetic data become available in this area the determmation of the distribution of the diabasic intrusions will be greatly aided.

The Cretaceous(?) alkalic rocks encountered, both on outcrop and in drill hole, have apparent corresponding magnetic and gravity anomalies. The majority of these anomalies are positive, indicating that the igneous rock is more dense with a higher magnetic susceptibility (due to increased iron content) than the host rock. In addition to the known occurrences, gravity and magnetic patterns suggest the presence of additional igneous bodies in southeast and northeast Arkansas that have not been drilled. This interpretation is based on the shape and amplitude of the anomalies in question. Plate 2 shows the locations of both known and interpreted Phanerozoic intrusions within and directly adjacent to the State. These anomalies are discussed individually in relation to the proposed tectonic model.

\section{GEOPHYSICAL ANOMALIES ASSOCIATED WITH EXPOSED IGNEOUS ROCKS}

\section{LITTLE ROCK COMPLEX}

Outcrops of nepheline syenite and related rock occur within area $1 a$ of plate 2. Extensive drilling in this region by the U.S. Bureau of Mines indicates that the entire area is underlain by igneous rocks and represents a single body composed primarily of nepheline syenite. Due to their large number, drill holes in this area are not shown on plate 2. The majority of the body is covered by Paleocene and younger deposits, and depths to the top of the igneous body range from zero to more than $500 \mathrm{~m}$. Because of extensive deposits of bauxite, resulting from the weathering of the syenite, and the unusual character of the igneous rock, this area has been the subject of extensive petrographic (Williams, 1891), geophysical (Malamphy and Vallely, 1944), and geochemical and economic studies (Gordon and others, 1958). As indicated by Malamphy and Vallely (1944), the borders of the syenite body are marked by a sharp break in the Bouguer gravity gradient, and the igneous body corresponds with a gravity "low" of approximately $25 \mathrm{mGal}$. Because the body apparently produces a gravity minimum, the igneous rock must be less dense than the rock it intruded. Density determinations by Malamphy and Vallely (1944) indicated the syenite averages $2.52 \mathrm{~g} / \mathrm{cm}^{3}$ with the surrounding Paleozoic rock averaging $2.58 \mathrm{~g} / \mathrm{cm}^{3}$, a contrast of $0.06 \mathrm{~g} / \mathrm{cm}^{3}$.

When viewed on a more regional basis, it is obvious that the gravity "low" that appears to be directly related to the igneous complex is surrounded by a gravity "high" nearly $50 \mathrm{~km}$ in diameter (1b of pl. 2). The cause of this positive anounaly is not apparent from rocks encountered at the surface or from drill holes within the area. One interpretation is that this "high" corresponds to a deep-seated magma chamber from which the nepheline syenite was derived. Basic to ultrabasic igneous rocks have been identified within and directly adjacent to the igneous complex at Little Rock. On the extreme southern edge of anomaly $1 b$, near the town of Sheridan, the Shafer Oil and Refining, Youngblood No. 1 well (well $b$, pl. 2; table 1) penetrated pyroxenite at a depth of 687 $\mathrm{m}$. This occurrence corresponds to a gravity anomaly of about $+5 \mathrm{mGal}$ and an aeromagnetic anomaly of about +800 gammas (Hildenbrand and others, 1981). A similar but somewhat larger (in area) $+13 \mathrm{mGal}$ gravity anomaly occurs southeast of the town of Benton. Malamphy and Vallely (1944) attributed this anomaly to another pyroxenite plug possibly at a greater depth than the one near Sheridan. The presence of these mafic to ultramafic coinagmatic rocks within the complex suggests fractionation and differentiation of a deep-seated body. 
Figure 6 is a geophysical model for the igneous complex at Little Rock derived from gravity and magnetic anomalies. In this model the densities are in the range

of those measured by Malamphy and Vallely (1944) and are used for control of surface and near-surface rocks. The horizontal dimension of the upper surface of the
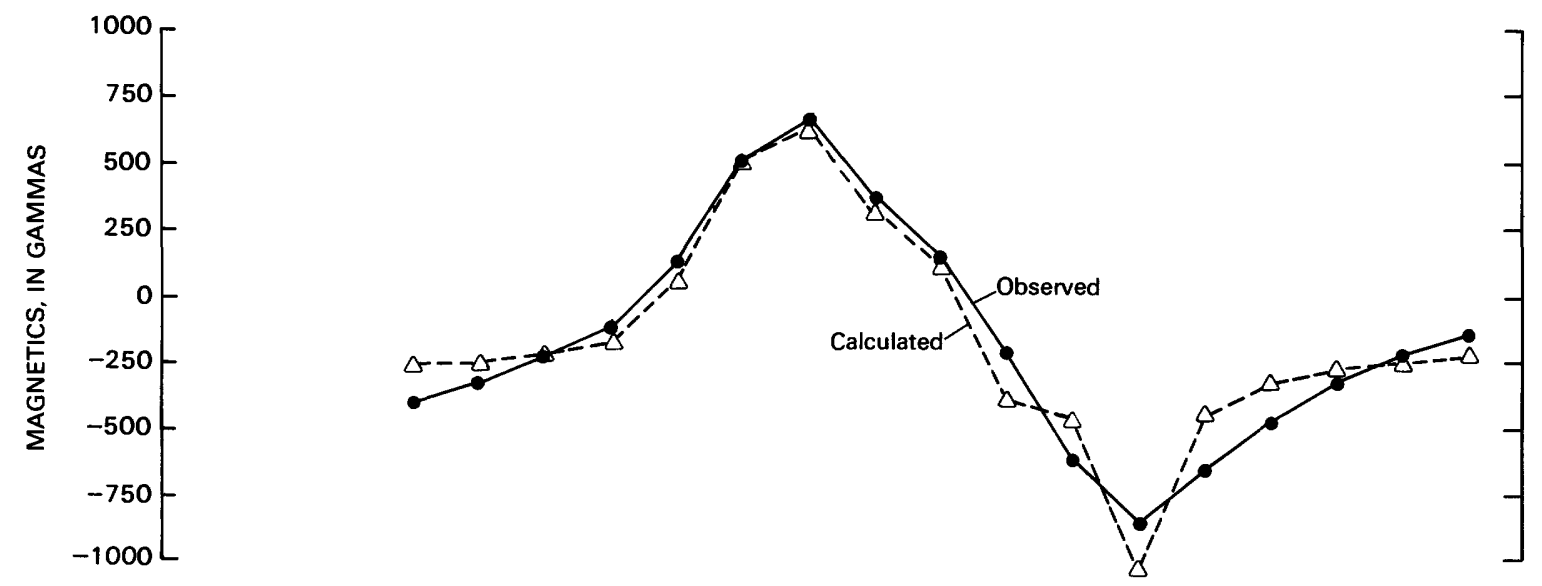

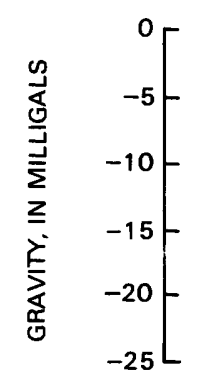
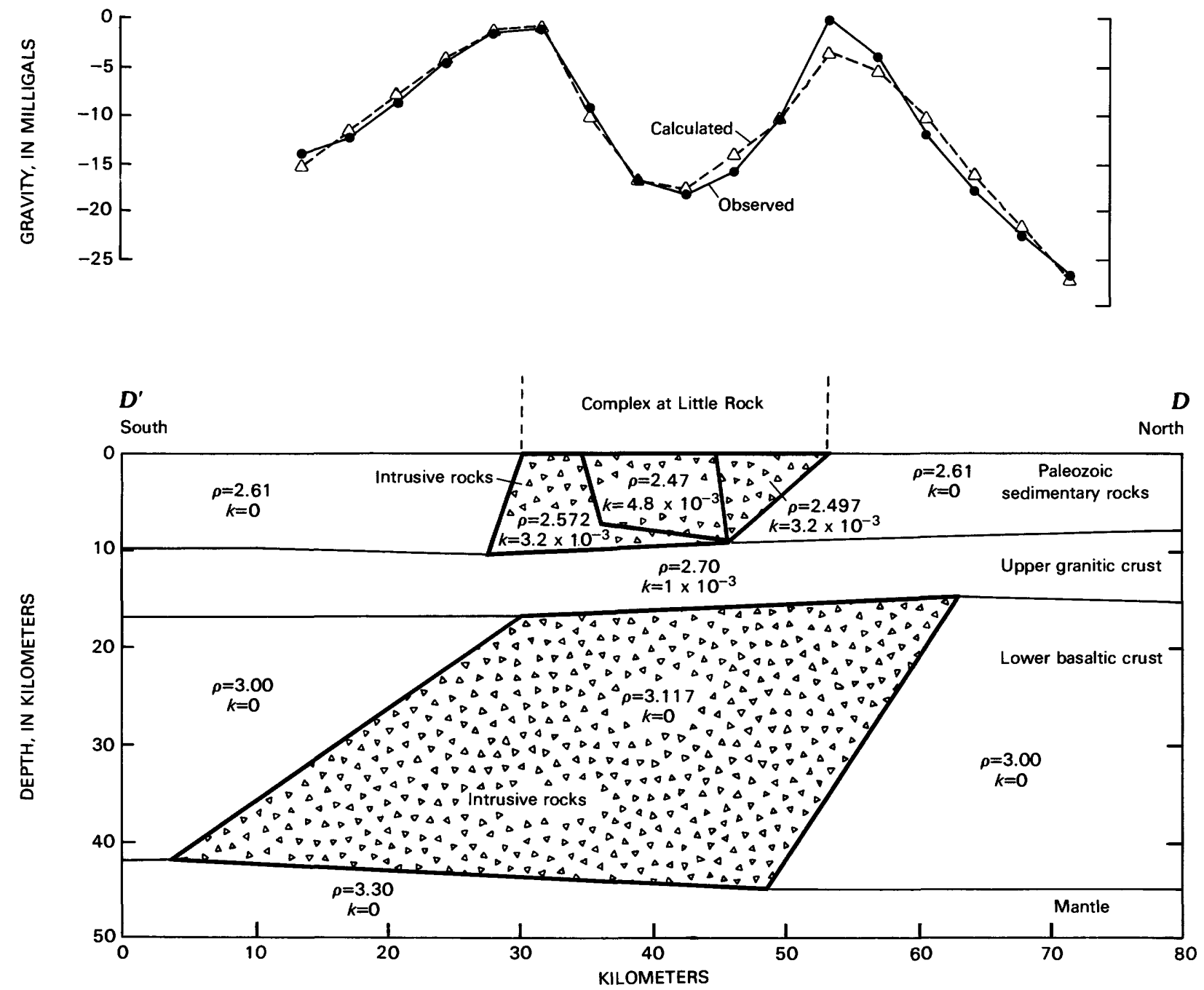

FIGURE 6.-Graph and cross section showing gravity and magnetic model of the igneous complex at Little Rock. (See pl. 2 for profile location $D-D^{\prime}$.) Rho $(\rho)$, density in grams per cubic centimeter; $k$, magnetic susceptibility, in cgs units. 
nepheline syenite body is that shown by Gordon and others (1958, pl. 5). The magnetic susceptibilities for igneous rocks of the complex at Little Rock used in constructing figure 6 are slightly higher than those measured by Malamphy and Vallely (1944) from surface and near-surface samples. The implied higher susceptibilities may reflect the nonweathered magnetic character of the igneous rock at depth. Deeper unsampled units (crystalline basement and lower crust) are estimates, and the magma body (shown encompassing the lower crust) is assumed to have the physical properties reported by Malamphy and Vallely (1944) for ultrabasic rocks of the area. The base of the parent magma body corresponds to the base of the crust (approximately $40 \mathrm{~km}$ ). Paleocene deposits that overlie the batholith are neglected in the model as they produce anomalies of only local extent (Malamphy and Vallely, 1944). Although the use of the measured and estimated physical properties of the units, lateral dimensions of the nepheline syenite body, and the thickness of the crust may have some validity in the geophysical model, the location (depth) of the parental magma body-if it is present at all-is purely speculative. Assuining that such a body exists, the only constraint on its location is that it be confined to the crust (a positive density contrast) and that it be below the Curie isotherm (approximately $16 \mathrm{kun}$; Lyons, 1961) because it apparently lacks a corresponding magnetic anomaly (fig. 6). An identical gravity and magnetic pattern can be derived by leaving the physical properties the same and simply changing the depth and shape of this body. If, however, the parental body wholly or partly intrudes upper crustal (granitic) rocks, its vertical extent would be much less than is shown in figure 6 because the density contrast between this body and the surrounding rocks would be increased.

The origin of silica-undersaturated igneous rocks is a subject of much discussion in the geologic literature. Currently, a majority of petrologists favor the hypothesis that highly undersaturated igneous rocks result from fractionation and differentiation of an alkali basalt magma possibly resulting from anatexis of the upper mantle or lower crust. This is especially true of large nepheline syenite bodies such as the igneous complex at Little Rock. One possible problem is the volume of nepheline syenite within the Little Rock batholith implied by the model presented in figure 6 , which is about 15-20 percent of that of the total original parental magma. If, as has been suggested (Turner and Verhoogen, 1960, p. 390), the volume proportion of nepheline syenite produced by the above process is small compared with the volume of the original melt, this apparent discrepancy may be explained as follows: (1) the igneous complex at Little Rock, as a whole, is a more basic intrusion, and the nepheline syenite is confined to the upper parts of the body, and (or) (2) the parental magma occupied a much larger volume than is suggested in figure 6. Assuining that the densities employed in constructing figure 6 are correct, or nearly so, the volume of the lightweight fraction (nepheline syenite) must remain the same in order to produce the observed anomaly regardless of whether or not this fraction is disseminated throughout a more mafic fraction. This negates the first explanation. The prospect that the original magma occupied a much larger area than is implied by plate 2 has some merit. The Bouguer gravity field in southeast Arkansas is characterized by circular anomalies that have steep gradients, are on the order of 10-30 km in diameter, and have amplitudes of +15 to $+20 \mathrm{mGal}$. These gravity features appear to correlate with alkalic volcanic plugs and stocks of probable Cretaceous age (Moody, 1949). Similar anomalies are noted in northeast Louisiana and central Mississippi. All these anomalies are superimposed on a broader, longer wavelength gravity high (fig. 2). This gravity ridge may represent the presence of a deep-seated crustal residual fraction of a magma body remaining when lighter weight differentiates intruded the upper crust.

The igneous complex at Little Rock occurs at the junction of the Ouachita structural belt and the northwest border fault of the Mississippi Valley graben (pl. 2). Alkalic volcanism in this part of the North American continent probably represents reactivation of rifting that began in Triassic-Jurassic time with the separation of Gondwanaland and Laurasia (Burke and Dewey, 1973). This period of igneous activity appears to have ended abruptly about 90 m.y. ago, although there is a suggestion of minor continuation into the Tertiary Period (Hendricks and Glick, 1979; Glick, 1982).

\section{MAGNET COVE COMPLEX}

Magnet Cove Complex is the name given to a $12 \mathrm{~km}^{2}$ alkalic ring dike complex that crops out in the extreme eastern Ouachita Mountains (pl. 2, Magnet Cove anomaly). Based on rock type, the complex is divided into three areas: an ijolite core, an intermediate ring of trachyte and phonolite, and an outer ring of nepheline syenite and jacupirangite (Williams, 1891; Washington, 1900; Erickson and Blade, 1963). Although much is known about the petrology, geochemistry, and resulting petrogenesis of the Magnet Cove Complex (Erickson and Blade, 1963), very little information regarding the subsurface distribution of the igneous rocks is available. Washington (1900) believed that the rocks observed at the surface resulted from in-place differentiation of a laccolithic intrusion. Erickson and Blade (1963) suggested that the rocks observed at Magnet Cove represent fractionation 
and differentiation of a melanocratic phonolitic magma that was, in turn, derived from a regional undersaturated olivine basaltic melt. The different rock types observed at Magnet Cove result from this process along with tapping of different levels of the magma chamber over a relatively short period of time.

Based on Washington's (1900) suggestion of a laccolithic type intrusion, a model (fig. 7) was computed from gravity and magnetic measurements. For the gravity model, a contrast in density of $+0.3 \mathrm{~g} / \mathrm{cm}^{3}$ was assumed for igneous versus sedimentary rocks. The method used in constructing this model is twodimensional but is limited perpendicular to the profile at $4 \mathrm{~km}$. Results of this gravity modeling show that the Bouguer anomaly observed at Magnet Cove can be duplicated by a laccolith-shaped body with its top at the surface and base at a depth of about 7-9 km. The implied slopes on the margins range from $31.5^{\circ}$ on the north to about $60^{\circ}$ on the south (fig. 7).

The shape of the observed magnetic profile cannot be reproduced from the model just derived by applying a single magnetic susceptibility contrast to the rocks involved (igneous versus sedimentary). In fact, no model can be calculated using a single susceptibility contrast that matches the observed profile if the surface dimensions mapped at Magnet Cove are used. A susceptibility contrast of $25 \times 10^{-3} \mathrm{cgs}$ units will produce a calculated anomaly of the same amplitude as the observed profile (approximately 8,000 gammas at $300 \mathrm{~m}$ above ground), but the signature of the curves is quite different. The model shown in figure 7 is the simplest (it has the fewest bodies) that produces a reasonable correlation of calculated versus observed gravity and magnetic anomalies. This fit is accomplished by introducing a unit of high density and low magnetic susceptibility within the complex that roughly parallels the northern margin of the model. Does such a unit exist at Magnet Cove? If so, the most likely rock type, of those described by Erickson and Blade (1963), is that classified as altered phonolite and altered phonolite breccia. This rock, in which the original mafic iron-rich minerals have been altered to green biotite and calcite, occurs as an intrusive breccia and probably represents the first stages of igneous activity at Magnet Cove. Both alteration and brecciation will tend to reduce the apparent magnetic susceptibility-alteration by oxidation of the iron-bearing minerals and brecciation by disruption of any remanent magnetization. These processes, however, will not substantially affect the density. The model presented in figure 7 is obviously oversimplified due to the wide compositional variety of the exposed rocks at Magnet Cove, but it does provide a generalized working model for additional studies in this area.
POTASH SULPHUR SPRINGS INTRUSIVE BODY

The Potash Sulphur Springs intrusive body is located $10 \mathrm{~km}$ west of Magnet Cove and contains many of the same rock types. This body is much smaller in area than Magnet Cove and is associated with a $+5 \mathrm{mGal}$ gravity and a +100 gamma (at $300 \mathrm{~m}$ above ground) magnetic anomaly. These two complexes are probably genetically related and may represent vents originating from the same upper crustal magma chamber. If the dimensions of the body computed for Magnet Cove are approximately correct (radius $13 \mathrm{~km}$ ), then the Potash Sulphur Springs intrusive would be within its subsurface horizontal bounds. Models were not computed for this complex because of its proximity to the larger and more studied Magnet Cove intrusive.

\section{PERIDOTITE OF PIKE COUNTY OR KIMBERLITE AT MURFREESBORO}

Although somewhat less than $1 \mathrm{~km}^{2}$ in surface area and lacking corresponding geophysical anomalies (at the scale of the present surveys), the Murfreesboro volcanic pipe (Pike County peridotite) is important to this discussion because of its geographic location and implications to the regional tectonic setting. This volcanic neck occurs on the crest of a regional gravity ridge and is roughly aligned with the projection of the northwest border fault of the Mississippi Valley graben.

\section{GEOPHYSICAL ANOMALIES ASSOCIATED WITH IGNEOUS ROCKS IN DRILL HOLES}

\section{PERIDOTITE NEAR RISON IN GLEVELAND COUNTY}

The Arkansas Natural Gas Corporation Tate No. 1 well, located about $5 \mathrm{~km}$ west of Rison, Ark. (well $c$, pl. 2; table 1), encountered peridotite at a depth of 1,085 $\mathrm{m}$. The following description is taken from C.S. Ross (in Caplan (1954)):

3600 [ft] is a rock that is nearly black in hand specimen and contains conspicuous magnetite. The mineral composition is as follows:

Mineral composition of perovskite peridotite:

Olivine altered to (serpentine) $24 \%$

Primary magnetite (magnetite) $29 \%$

Perovskite

Mica

$13 \%$

Very small amounts of diopside

3616 [ft] This mimeral composition is as follows:

Mineral composition of peridotite:

Calcite

Olivine

Diopside

Mica

$31 \%$

Magnetite

$3 \%$

Serpentine

Perovskite

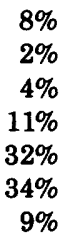

$8 \%$

$4 \%$

$11 \%$

$32 \%$

$9 \%$ 

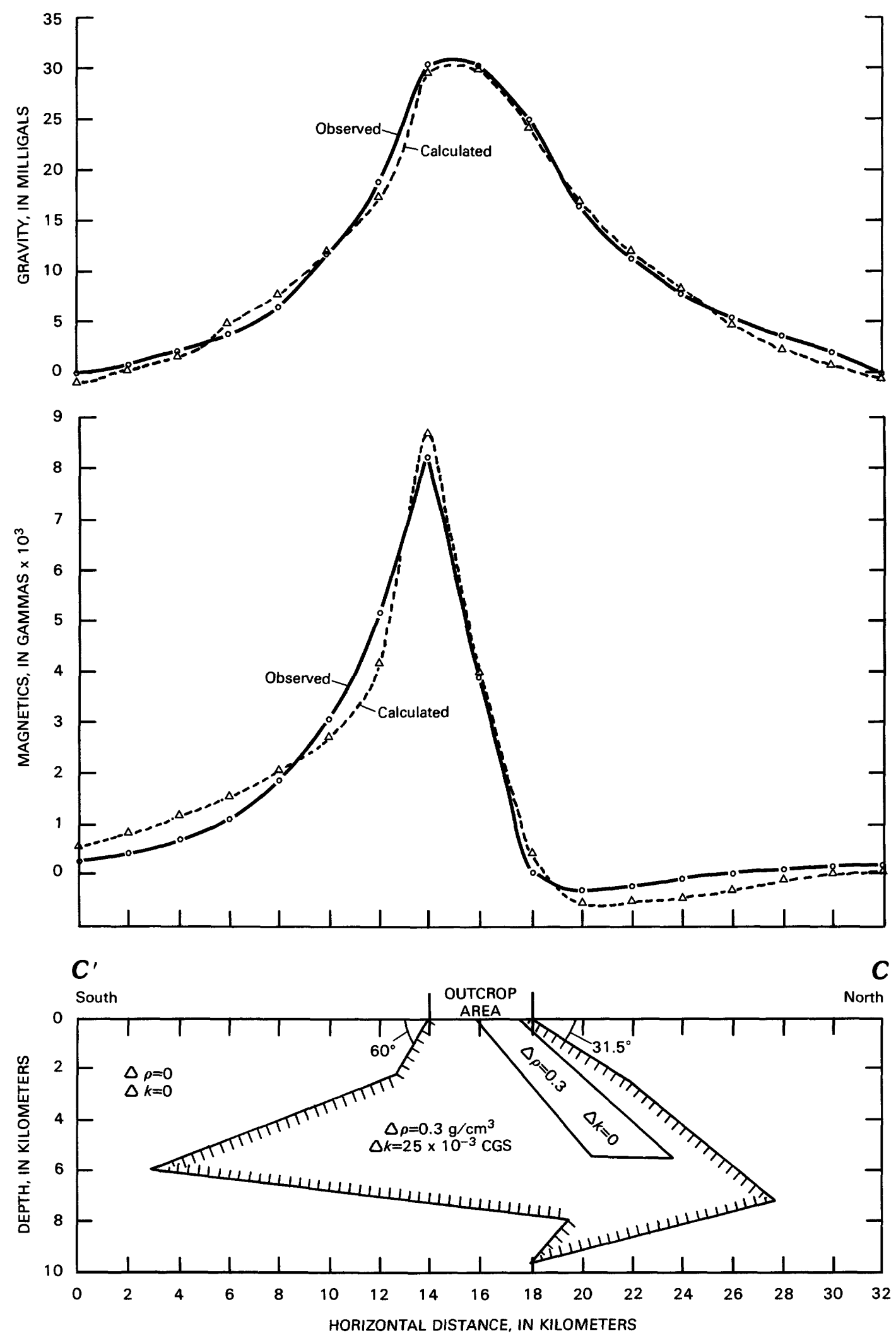

Figure 7.-Graph and cross section showing gravity and magnetic model of the Magnet Cove, Ark., area. (See pl. 2 for profile location $C-C^{\prime}$ ) Rho $(\rho)$, density in grams per cubic centimeter; $k$, magnetic susceptibility in cgs units. 
***Peridotite seems to have been encountered at about 3,561 feet where a serpentine derived from a nearly pure olivine rock was encountered. Below about 3,600 feet the rock is a peridotite of variable composition. Some parts are characterized by abundant magnetite and perovskite and others by mica, diopside and magnetite.

The rock from Rison, Cleveland County, is probably most closely allied in mineral composition with the diamond-bearing peridotite of Pike County, Arkansas. The gabbro-pyroxenite of Chicot County may also be related. Both rocks show hydrothermal metamorphism but no evidence of regional or dynamic alteration. This may mean that the rocks are later than pre-Cambrian and are related to the Cretaceous peridotites of Pike County in age as well as mineral composition.

The peridotite of the Cleveland County Tate well is overlain by about $75 \mathrm{~m}$ of somewhat metamorphosed Paleozoic(?) sediments that lie unconformably beneath Upper Cretaceous strata. If this intrusion is of Cretaceous age, the Paleozoic strata may represent either a roof pendant in the igneous rock or incomplete removal of overlying strata at the time of intrusion.

Gravity and magnetic anomalies associated with the Rison peridotite occurrence have approximately the same amplitude as that of the Magnet Cove complex (approximately 20-25 $\mathrm{mGal}$ and 8,000 gammas). The shape of the Rison anomaly (pl. 2), however, is more suggestive of a pluglike body than the implied laccolithic shape for Magnet Cove. The lack of any lightweight fraction observed so far at Rison may indicate that the magma migrated upward from a deep chamber without ponding in the upper crust long enough to allow extensive differentiation to take place.

\section{DUMAS ANOMALY}

A complex anomaly located near Dumas, Ark., consists of a circular gravity "high" with a central "low." Aeromagnetic data (Hildenbrand and others, 1981) suggest that this region may contain at least four volcanic intrusions that may be connected at fairly shallow depths. The area in which these anomalies are located is circular, roughly $25 \mathrm{~km}$ in diameter (pl. 2). Two drill holes within the outline on plate 2 have penetrated igneous rock directly beneath Cretaceous sediments about $1,500 \mathrm{~m}$ deep. The Columbian Gas Company, Victoria Cross Lumber Company No. 1 well (well $d$; table 1 ) in the northeastern part of the area produced a sample that is described as a normal syenite or diorite (Caplan, 1954, p. 112-113). Chemical analysis of this rock (Moody, 1949, table 1), however, shows that it is more typical of a nepheline syenite (Nockolds and Allen, 1954). The central gravity "low" may result from the presence of nepheline syenite concentrated in the upper-central part of the intrusion, with the gravity and magnetic "highs" related to more mafic material intruded around the borders and below the syenite.

\section{DIABASE(?) IN DREW COUNTY}

Two boreholes, one in northern Drew County (well $e$ ) and the other in southern Cleveland County (well $f$, have found igneous rock. The Drew County well rock was classified as diabase (Moody, 1949) but was not described. The Cleveland County igneous rock was indicated by Stone and Sterling (1964) as being an alkalic intrusive or volcanic rock-also not described. Both these wells are located on the northern end of an arcuate $+10 \mathrm{mGal}$ gravity ridge (pl. 2). Whether this ridge results from the presence of igneous material at depth will have to be determined from further drilling and geophysical surveys in the area.

\section{CHICOT AND ASHLEY COUNTIES ANOMALY}

At least 13 deep wells in extreme southeast Arkansas have penetrated igneous rock. Compositions of the recovered samples vary from pyroxenite to quartzbearing syenite. Two of the wells passed through either dikes or sills reentering sedimentary rocks and bottoming again in igneous rock. The A. Plummer, Crossett Lumber Company No. 1 (well $g$; table 1), located $10 \mathrm{~km}$ east of Hamburg, Ashley County, Ark., drilled into an apparent volcanic neck at a depth of approximately $1 \mathrm{~km}$ (A.L. Kidwell, in Caplan, 1954). In this same region quartz-bearing syenite was recovered from two wells in northeast Ashley County. The quartz is believed to represent both assimilation of siliceous country rock and primary quartz (C.L. Moody, in Caplan, 1954). With the exception of these two occurrences, the igneous rocks of this area have alkaline affinities. Occurrences of intrusive rocks in this southeast Arkansas region are only part of a much larger area characterized by Cretaceous(?) alkalic rocks in northeast Louisiana, westcentral Mississippi, and Arkansas in which "Virtually every well***which has been drilled through the Upper Cretaceous section has pierced beds which are in part, at least, composed of fragmented igneous rocks produced as lapilli or ash in the throats of volcanoes which dotted the late Mesozoic landscape" (Moody, 1949, p. 1410).

It is apparent, from figure 2, that the occurrence of igneous rock in this tri-State area corresponds to at least four separate positive gravity anomalies. In extreme southeast Arkansas, wells that have igneous finds are associated with an east-west elongate elliptical Bouguer gravity maximum of $+25 \mathrm{mGal}$ with semimajor and semiminor axes of $50 \mathrm{~km}$ and $30 \mathrm{~km}$, respectively (pl. 2). This anomaly is similar to those of the complex at Little Rock and Dumas area in that it is a gravity "high" with a central gravity "low." The wide range of rock 
types and variable gravity values in the area suggest that if indeed this anomaly is the signature of an upper crustal intrusion, it has undergone extensive differentiation. The central gravity low may represent the presence of a late-forming, lightweight magmatic fraction surrounded by a series of mafic to ultramafic plugs and dikes.

\section{COVINGTON AND MILLINGTON, TENNESSEE}

Igneous rocks have been noted in wells near Covington and Millington in extreme western Tennessee. Near Millington, the Lion Oil Company No. 1 Bateman (well $h$; table 1 ) went from Upper Cretaceous sedimentary rocks into normal syenite (Caplan, 1954) at a depth of about $900 \mathrm{~m}$. Detailed geophysical surveys have not been conducted in this area; however, regional gravity and magnetic anomaly maps show that this occurrence is on the crest of a northeast-trending geophysical ridge. This location also corresponds to the southeast border fault of the Mississippi Valley graben (Kane and others, 1981).

The Pure Oil Company McGregor No. 1 well (well $i$; table 1), located near Covington, Tenn., found igneous rock at the base of the Upper Cretaceous Nacatoch Sandstone. The rock recovered from this well is described as a normal syenite (Caplan, 1954) and nepheline syenite (Kidwell, 1951). This well is centered on a circular gravity and magnetic high. Regional gravity values (fig. 2) suggest that the Bouguer anomaly associated with this igneous occurrence is as much as $65 \mathrm{~km}$ in diameter. The corresponding magnetic anomaly, however, is only about $15 \mathrm{~km}$ in diameter. The amplitudes of the gravity and magnetic anomalies are $+45 \mathrm{mGal}$ and $+1,300$ gammas respectively (Smith, 1974). The Bouguer gravity pattern may be duplicated by modeling using a vertical cylinder (plug type intrusion) (Phelan, 1969; Smith, 1974; fig. 5). When compared with other anomalies believed to be related to igneous intrusions in the region-Magnet Cove, for examplethe Covington feature shows a larger gravity anomaly $(+45$ versus $+30 \mathrm{mGal}$ ) and much smaller magnetic departure ( $+1,300$ versus 8,000 gammas). This may indicate that the upper $10 \mathrm{~km}$ or so of the Covington feature is composed of a mixture of felsic and intermediate fractions of a differentiated magma, and the basic and ultrabasic fractions remaim at depth. In this case the upper part of the body would have a density very near that of the country rock (upper crystalline crust and Paleozoic section) and a very small magnetic susceptibility contrast. This igneous feature also occurs along the southeast border fault of the Mississippi Valley graben.

\section{SUSPECTED INTRUSIVE BODIES}

\section{ASSOCIATED ANOMALIES NEAR RISON}

Three gravity and magnetic anomalies occur immediately northeast of the Rison anomaly $2 a$ (pl. 2). These are circular with the largest [3c] having an amplitude of $+23 \mathrm{mGal}$ and about 5,000 gammas. If these result from igneous intrusions, anomalies $3 b$ and $3 c$ appear to be directly related. These two anomalies are separated from $3 a$ by about $25 \mathrm{~km}$. The combined shape of $3 b$ and $3 c$ is very similar to the gravity and magnetic anomalies observed at Magnet Cove-Potash Sulphur Springs. This suggests the possibility that these two anomalies represent cupolas from an upper crustal chamber. Because these anomalies have not been drilled, the rock types involved in causing the anomalies are unknown.

Anomaly $3 a$, centered $12 \mathrm{~km}$ southwest of Pine Bluff, Ark., has the same lateral dimensions as $3 c$ and the Rison anomaly (approximately $18 \mathrm{~km}$ in diameter), but the departures in the gravity and magnetic fields here are only $+11 \mathrm{mGal}$ and $+1,200$ gammas, respectively. Because of its circular shape and geographical association with known intrusive bodies, anomaly $3 c$ is also ascribed to igneous activity. The cause of the reduced amplitudes associated with this suspected intrusion is probably a combination of greater depth to the source, vertically smaller body if it is an upper crustal magma chamber, and possibly a lighter weight and less magnetic composition of the causative rock as compared to other intrusions of the province.

\section{NEWPORT ANOMALY}

The Newport anomaly ( $3 d$; pl. 2) is located near the northwest margin of the Mississippi embayment, $10 \mathrm{~km}$ west of Newport, Ark. Gravity and magnetic maps of the region (Hildenbrand and others, 1981) show that this anomaly is a double-peaked feature elongate in a north-south direction. The total magnetic field observed in this area was first discussed by Jespersen (1964), who believed the anomaly resulted from a mass within the Precambrian basement whose top is about $1.6 \mathrm{~km}$ below the surface. Model studies (figs. 8-10) suggest that the top of the body corresponds to regional magnetic basement in this area and that the observed gravity and magnetic curves can be closely approximated by using a rectangular body with a single density and susceptibility contrast. By employing the two-dimensional inverse method of varying the shape and physical properties of the anomalous body until the observed anomaly is approximated, it is determined 

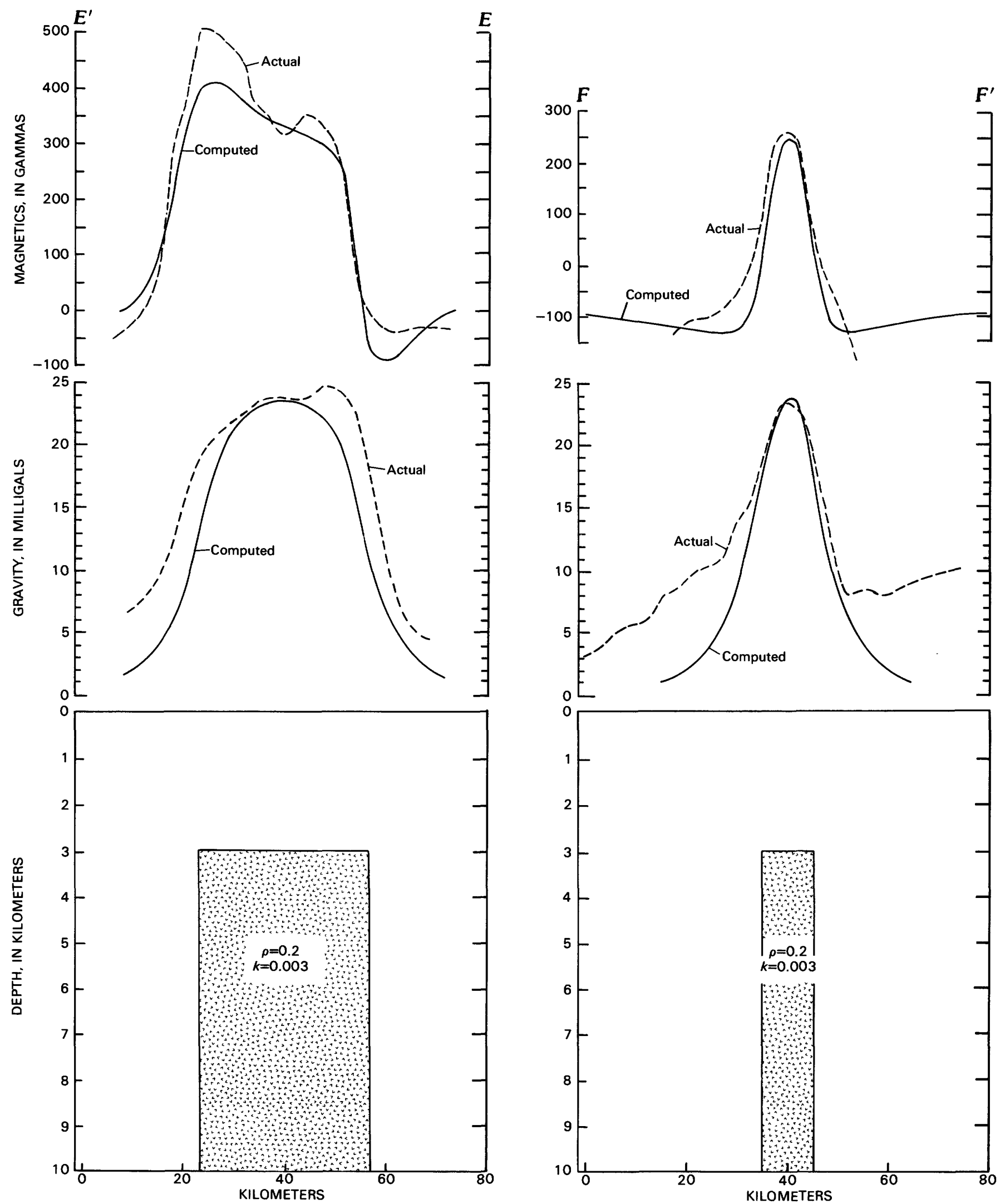

FigURE 8.-Graphs and cross sections showing gravity and magnetic models of the Newport, Ark., area. (See pl. 2 for profile locations $E$ - $E^{\prime}$ and $F-F^{\prime}$ ) Rho $(\rho)$, density contrast between body and surrounding rock, in grams per cubic centimeter; $k$, magnetic susceptibility contrast in cgs units. 


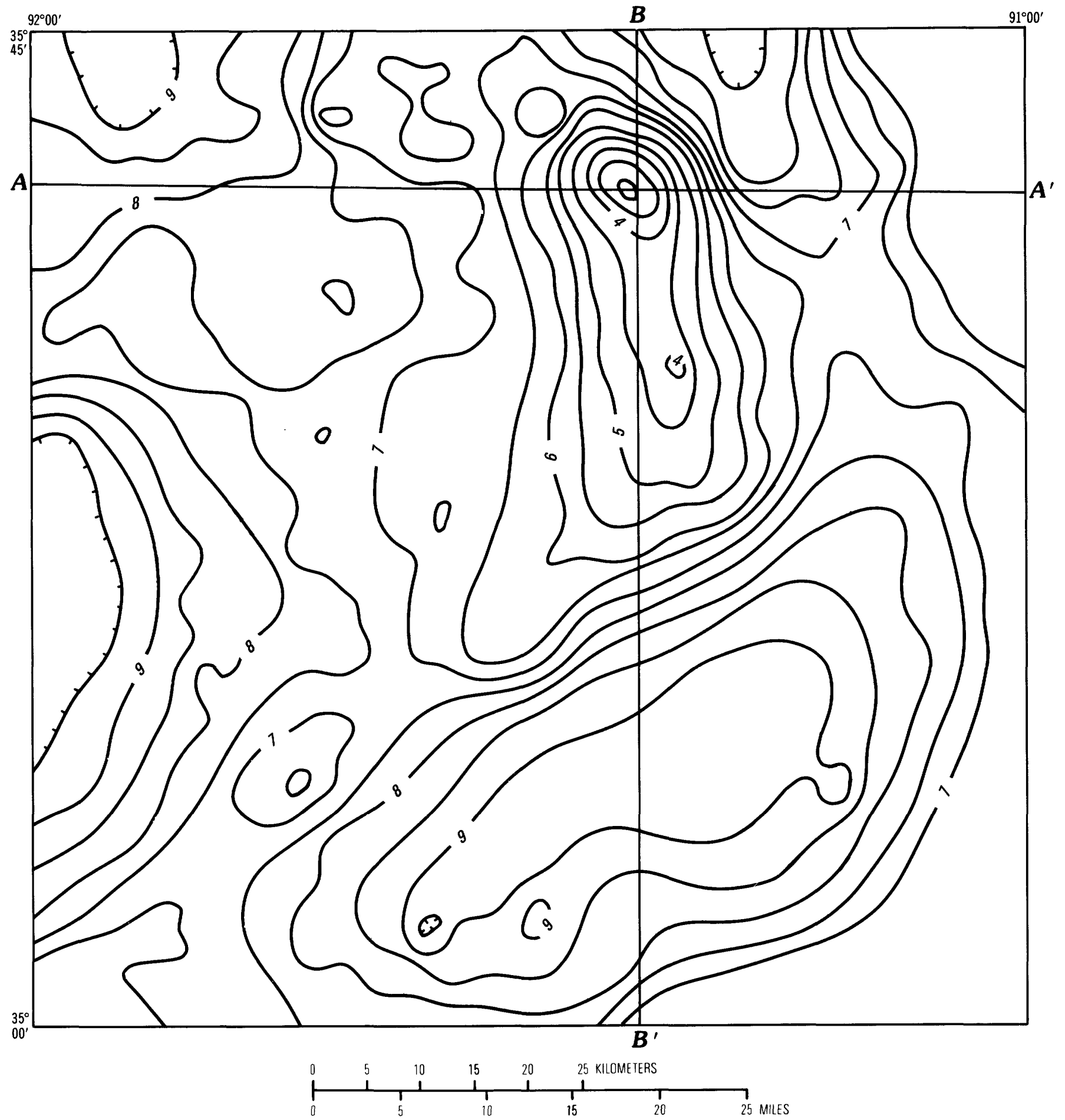

FIGURE 9.-Map of Newport, Ark., area showing distribution of the hypothetical $+0.2 \mathrm{~g} / \mathrm{cm}^{3}$ body from figure 8. Reference plane defines base of body at $10 \mathrm{~km}$; contour interval $0.5 \mathrm{~km}$; hachures indicate closed low. Profiles $A-A^{\prime}, B-B^{\prime}$ on figure 10.

that a $+0.2 \mathrm{~g} / \mathrm{cm}^{3}$ density and $3 \times 10^{-3} \mathrm{cgs}$ units susceptibility contrast, along with the dimensions shown in figure 9, give a good correspondence for this anomaly. The mass distribution shown in figure 9 is derived from the forward three-dimensional gravity method developed by Cordell and Henderson (1968) with the density contrast determined from the two-dimensional method described previously. Results of these exercises suggest that the anomaly is caused by the presence of a mafic stock intruded into the upper crust. 

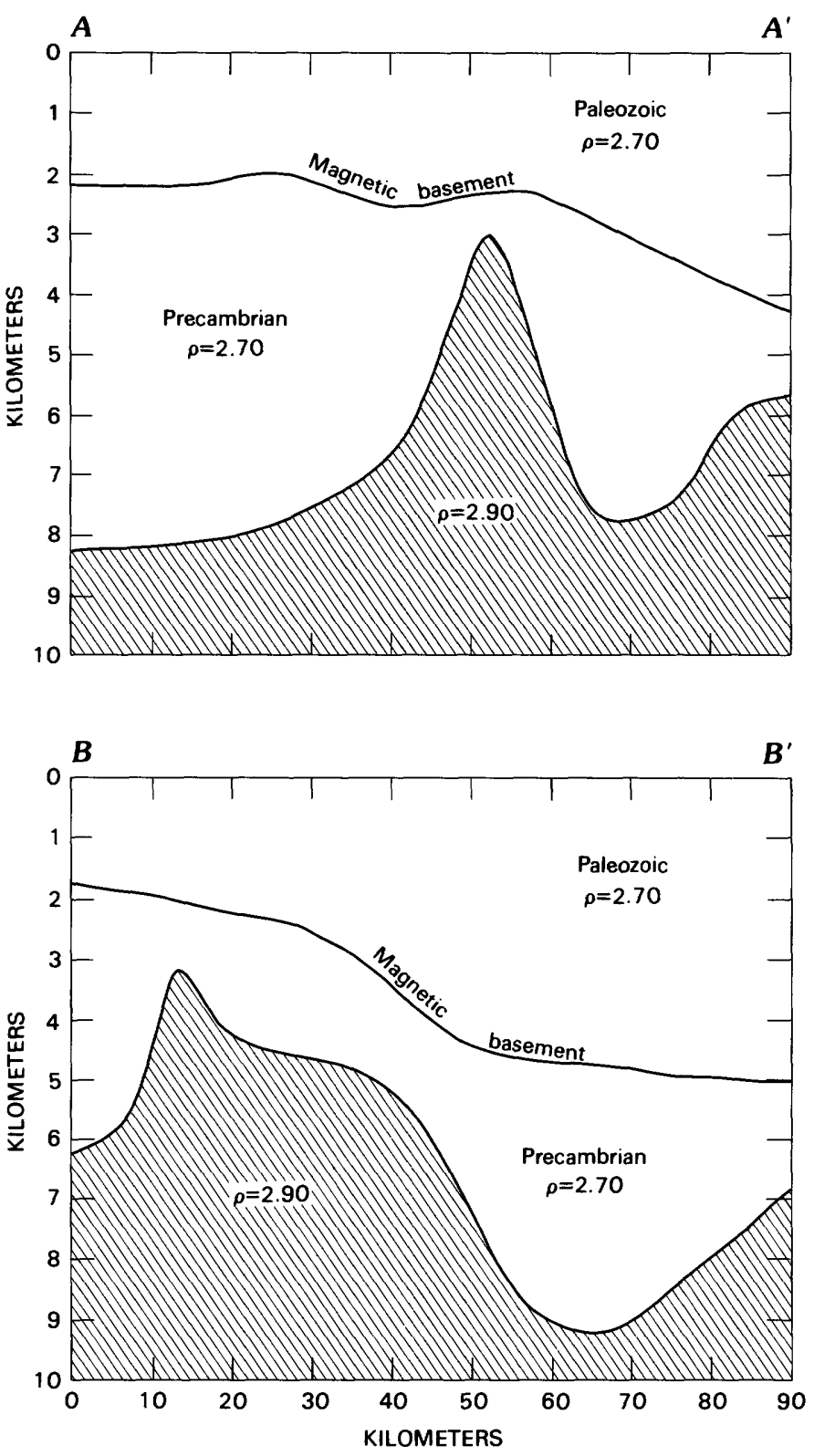

Figure 10.-Cross sections (N-S and E-W) from figure 9. Magnetic basement taken from Hildenbrand and others (1980). Rho ( $\rho)$, density in grams per cubic centimeter.

The age of this suspected intrusion is unknown. This anomaly is only one of a series that characterize the northwest margin of the Mississippi Valley graben, suggesting a genetic relation between the causative bodies. If the graben formed in late Precambrian, as suggested by Ervin and McGinnis (1975), or in earliest Cambrian time, then the intrusions that mark its boundaries are most probably of the same or younger age. Three of the graben border intrusions (Little Rock, Magnet Cove, and Covington) are Late Cretaceous in age and are related to rift reactivation. Whether the remaining border intrusions are also Cretaceous is unknown. In the case of the Newport feature, although the igneous body appears to be confined to the Precambrian basement, detailed geologic mapping by Glick (1982) indicates that beds as young as post-Paleocene are locally uplifted as much as $150 \mathrm{~m}$ over the crest of the anomaly. The coincidence of this uplift and geophysical anomaly suggests the intriguing possibility of igneous activity in this region extending well into Tertiary time.

\section{JONESBORO, MARMADUKE, SEDGWICK, AND WALNUT RIDGE}

Gravity and magnetic anomalies that closely resemble the Newport feature in amplitude and horizontal extent are noted in northeast Arkansas (pl. 2) near the towns of Jonesboro, Marmaduke, Sedgwick, and Walnut Ridge. The Jonesboro and Sedgwick anomalies are close to one another and may represent cupolas of the same intrusive body. These two anomalies, along with the Marmaduke feature, define this part of the northwest margin of the Mississippi Valley graben. The Walnut Ridge gravity and magnetic high, although still in the Mississippi embayment, is displaced to the west of the suggested graben and may be related to Precambrian igneous activity in the Ozarks region. None of the bodies causing these observed anomalies have been penetrated by drill and, like the Newport feature, appear to be confined to the Precambrian basement.

\section{PIGGOTT "LOW"}

A circular gravity and magnetic low about $30 \mathrm{~km}$ in diameter is located in the extreme northeast corner of Arkansas (pl. 2), near the town of Piggott. Gravity values show a $-10 \mathrm{mGal}$ departure with a corresponding -200 gamma magnetic anomaly. This feature also is located west of the Mississippi Valley graben and appears to be more akin to anomalies observed in the Ozarks region. Here gravity and magnetic signatures are suggestive of a granitic stock intruded into a metamorphic terrane. If this is the case, the causative body was probably formed in Precambrian time and may be related to acidic volcanism of the St. Francois Mountains.

\section{RELATION OF IGNEOUS INTRUSIONS TO PROPOSED TECTONIC MODEL}

In the tectonic model proposed herein, the location of known and suggested igneous bodies defines the limits of some of the major structural features. In northeast Arkansas and western Tennessee, the borders of 
the Mississippi Valley graben are, for the most part, located by basic to ultrabasic igneous bodies. All the intrusions that have been dated, either by radiometric or stratigraphic methods, are Late Cretaceous or younger (Newport), which reflects probable reactivation of the Reelfoot rift (Ervin and McGinnis, 1975) during this period. The location of the Murfreesboro diamond pipe (also Late Cretaceous) suggests continuation of the northwest border fault in that direction. The southeasttrending line of Cretaceous alkalic intrusives, heading at Little Rock, marks the proposed strike-slip fault that forms the northeast edge of the Ouachita mobile block. In southwestern Arkansas, Triassic(?)-Jurassic diabase probably intruded along normal graben faults that formed during the early stages of the separation of Gondwanaland and Laurasia.

One other important aspect of the alkalic rock suite in this region is that it is generally thought of as being related to major structural features within continental areas. The occurrence of these types of rocks in proximity to the Ouachita structural belt argues against subduction as the mechanism of formation of the system.

\section{SUMMARY}

The Bouguer gravity anomaly map of Arkansas (Hendricks and others, 1981; pls. 1 and 2) shows a definite relation between gravity patterns and physiographic provinces and sections, which in turn are related to tectonic events that span the range of geologic time from Precambrian to Tertiary.

In the Arkansas Ozark Plateaus province, the Bouguer anomaly can be separated into two areas: the northeast part of the province, in which the gravity is quite variable, consisting of ridges, troughs, and circular "highs"; and the west-central Ozarks where the gravity is at a reduced level and lacks well-developed trends. Major gravity anomalies in this province probably resulted from changes in lithology in the Precambrian basement. In the northeast Arkansas Ozark Plateaus, basement may be similar to that classified as older crustal terrane in Missouri. If so, gravity ridges may represent areas of intermediate composition basement, gravity troughs then would occur over areas where the basement is of felsic composition, and circular gravity "highs" would be related to basic intrusions into this sequence. The west-central Ozarks may be underlain by basement similar to the St. Francois terrane in Missouri. This classification contains intrusive and extrusive rocks mainly of granitic composition. Mapped faults are reflected in the Bouguer anomaly in the Ozarks, the most prominent of which is the Mulberry system, which defines the southern margin of the province.

One of the most intense gravity "lows" in North America is associated with the Ouachita Mountains and Arkansas Valley sections. This anomaly results primarily from features formed during the Ouachita orogeny. A combination of increased thickness of the crust and of the sedimentary section appears to be the primary cause of this anomaly. The increase in thickness of the sedimentary section results from stacking by imbricate thrust faulting in the Ouachitas and original deposition in both physiographic sections.

The tectonic model presented in this report is an attempt to provide continuity to pre-Ouachita and Ouachita structural elements as well as to explain the location of Mesozoic alkalic intrusions. The following assumptions are made in this model: The pre-Ouachita paleogeography of the southeast North American continent was characterized by a passive margin that was made up of a number of rifted blocks (microcontinents). The region was under tension as the proto-Atlantic Iapetus ocean was spreading. This situation existed from the late Precambrian to the Upper Ordovician at which time a reversal of the stress field to a major northwestsoutheast compression occurred. Continuation of this compression, due to closing of the Iapetus ocean, eventually resulted in the Ouachita orogeny. If any subduction of this ocean basin occurred at the edge of North America, it was far southeast of the Ouachita system. The Ouachita Mountains, therefore, did not result directly from subduction but are a product of thin-skinned tectonics. During the Pangean configuration, the region between North and South America was completely occupied by the earlier formed rifted blocks. The breakup of Pangea in Triassic time allowed separation of these continental fragments along the previously formed boundaries. These pieces of continental crust are presently arranged around the periphery of the Gulf of Mexico.

It is proposed that the late Paleozoic deformation in the Ouachita Mountains and Gulf Coastal Plain was thin skinned; therefore, the more ancient, deep-seated rift and associated transform faults were preserved below the thrust sheets. Rift reactivation in Mesozoic time produced a regional alkalic magma that migrated into the upper crust along these early-formed, deep-seated fault systems. Gravity and magnetic anomalies associated with these intrusions suggest that some ponded and differentiated in the upper crust and others appear to have migrated directly upward from the lower crust. North of the Ouachita structural belt, Cretaceous igneous activity was along reactivated border faults of the Mississippi Valley graben.

The Mississippi embayment contains evidence of three separate tectonic and igneous events. The first is a late 
Precambrian rifting event that is preserved in the northern part of the embayment. The gravity here is characterized by relatively high Bouguer values that probably reflect the presence of high-density igneous bodies intruded along reactivated border faults of the rift graben in Cretaceous time. The other two tectonicigneous events are reflected in the gravity field of the southern embayment: (1) the late Paleozoic Ouachita orogeny, which formed southeast-trending structures reflected in the Bouguer anomaly, and (2) upper crustal Mesozoic intrusions and possible deep-seated magma bodies.

The gravity of the West Gulf Coastal Plain section is characterized by anomalies of low amplitude that are separated by areas of high gravity gradients. The anomalies appear to result from discontinuities in the crust below the level of present drill-hole information. Regions of steep gravity gradient may be associated with early Mesozoic diabasic intrusions.

\section{REFERENCES CITED}

ACIC (Aeronautical Chart and Information Center, United States Air Force), 1973, World relative gravity reference network: Revisions to ACIC Reference Publication 25, St. Louis, Missouri.

Bickford, M.E., Harrower, K.L., Hoppe, W.J., Nelson, B.K., Nusbaum, R.L., and Thomas, J.J., 1981, Rb-Sr and U-Pb geochronology and distribution of rock types in the Precambrian basement of Missouri and Kansas: Geological Society of America Bulletin, v. 92 , no. 6, p. $323-341$.

Briggs, G., and Roeder, D.H., 1975, Sedimentation and plate tectonics, Ouachita Mountains and Arkoma Basin, in Briggs, G., McBride, E.F., and Moiola, R.J., eds., Sedimentology of Paleozoic flysch and associated deposits, Ouachita Mountains-Arkoma Basin, Oklahoma: Dallas Geological Society, p. 1-22.

Burke, K., and Dewey, J.F., 1973, Plume generated triple junctionsKey indicators in applying plate tectonics to old rocks: Journal of Geology, v. 81, p. 406-433.

Caplan, W.M., 1954, Subsurface geology and related oil and gas possibilities of northeastern Arkansas: Arkansas Resource and Development Commission Bulletin 20, 124 p.

Cebull, S.E., and Shurbet, D.H., 1980, The Ouachita belt in the evolution of the Gulf of Mexico, in Pilger, R.H., Jr., The origin of the Gulf of Mexico and the early opening of the central North Atlantic Ocean: Louisiana State University Symposium, p. 17-26.

Cline, L.M., and Shelburne, O.B., 1959, Late Mississippian-Early Pennsylvanian stratigraphy of the Ouachita Mountains, Oklahoma, in Cline, L.M., Hilseweck, W.J., and Feray, D.E., eds., The geology of the Ouachita Mountains: Dallas Geological Society, Ardmore Geological Society, p. 175-207.

Cook, F.A., Albaugh, D.S., Brown, L.D., Kaufman, S., Oliver, J.E., and Hatcher, R.D., Jr., 1979, Thin-skinned tectonics in the crystalline southern Appalachians; COCORP seismic-reflection profiling of the Blue Ridge and Piedmont: Geology, v. 7, no. 12, p. 563-567.

Cordell, L., 1977, Regional positive gravity anomaly over the Mississippi embayment: Geophysical Research Letters, v. 4, no. 7, p. 285-287.
Cordell, L., and Henderson, R.G., 1968, Iterative three-dimensional solution of gravity anomaly data using a digital computer: Geophysics, v. 33 , no. 4 , p. 596-601.

Denison, R.E., 1966, Basement rocks in adjoining parts of Oklahoma, Kansas, Missouri, and Arkansas: University of Texas Austin Ph. D. thesis, 328 p.

Denison, R.E., Burke, W.H., Otto, J.B., and Hetherington, E.A., 1977, Age of igneous and metamorphic activity affected by the Ouachita fold belt: Symposium of the Geology of the Ouachita Mountains, Arkansas Geological Commission, v. 1, p. 25-40.

Dietz, R.S., and Holden, J.C., 1972, The breakup of Pangaea, in Continents adrift: San Francisco, W.H. Freeman and Company, p. 102-113.

Erickson, R.L., and Blade, L.V., 1963, Geochemistry and petrology of the alkalic igneous complex at Magnet Cove, Arkansas: U.S. Geological Survey Professional Paper 425, 95 p.

Ervin, C.P., and McGinnis, L.D., 1975, Reelfoot Rift-reactivated precursor to the Mississippi embayment: Geological Society of America Bulletin, v. 86, no. 9, p. 1287-1295.

Fenneman, N.M., 1946, Physical divisions of the United States: U.S. Geological Survey, Washington, D.C., scale 1:7,000,000.

Flawn, P.T., 1959, The Ouachita structural belt, in Cline, L.M., Hilseweck, W.J., Feray, D.E., eds., The geology of the Ouachita Mountains: Dallas Geological Society, Ardmore Geological Society, p. 97-110.

Flawn, P.T., Goldstein, A., Jr., King, P.B., and Weaver, C.E., 1961, The Ouachita System: University of Texas Publication 6120, $401 \mathrm{p}$.

Glick, E.E., 1982, Stratigraphy and structure of post-Paleozoic sediments above the Newport pluton of northeastern Arkansas, in McKeown, F.A., and Pakiser, L.C., eds., Investigations of the New Madrid, Missouri, earthquake region: U.S. Geological Survey Professional Paper 1236, p. 150-174.

Goldstein, A., Jr., 1959, Petrography of Paleozoic sandstones from the Ouachita Mountains of Oklahoma and Arkansas, in Cline, L.M., Hilseweck, W.J., and Feray, D.E., eds., The geology of the Ouachita Mountains: Dallas Geological Society, Ardmore Geological Society, p. 97-110.

Gordon, Mackenzie, Jr., Tracey, J.I., Jr., and Ellis, M.W., 1958, Geology of the Arkansas bauxite region: U.S. Geological Survey Professional Paper 299, 267 p.

Graham, S.A., Dickinson, W.R., and Ingersoll, R.V., 1975, Himalayan-Bengal model for flysch dispersal in the AppalachianOuachita system: Geological Society of America Bulletin, v. 86, p. 273-286.

Haley, B.R., Glick, E.E., Bush, W.V., Clardy, B.F., Stone, C.G., Woodward, M.B., and Zachry, D.L., 1976, Geologic map of Arkansas: U.S. Geological Survey Map, scale 1:500,000.

Harris, L.D., and Bayer, K.C., 1979, Sequential development of the Appalachian orogen above a master décollement-A hypothesis: Geology, v. 7, p. 568-572.

Hayes, W.C., 1962, Configuration of the Precambrian surface showing major structural lineaments: Missouri Geological Survey and Water Resources unpublished map, scale 1:1,000,000.

Healy, J.H., and Warren, D.H., 1969, Explosion seismic studies in North America, in Hart, P.J., ed., The earth's crust and upper mantle: American Geophysical Union Monograph 13, p. 208-220.

Hendricks, J.D., and Glick, E.E., 1979, A crustal model of the Newport pluton derived from geological-geophysical studies: Geological Society of America Abstracts with Programs, v. 11, no. 2, p. 149.

Hendricks, J.D., Keller, G.R., and Hildenbrand, T.G., 1981, Bouguer gravity map of Arkansas: U.S. Geological Survey Geophysical Investigations Map GP-944, scale 1:500,000. 
Hendricks, T.A., 1959, Structure of the frontal belt of the Ouachita Mountains, in Cline, L.M., Hilseweck, W.J., and Feray, D.E., eds., The geology of the Ouachita Mountains: Dallas Geological Society, Ardmore Geological Society, p. 44-56.

Hildenbrand, T.G., Hendricks, J. D., and Kucks, R. P., 1981, Aeromagnetic map of central and northeastern Arkansas: U.S. Geological Survey Open-File Report 81-758, scale 1:500,000.

Hildenbrand, T.G., Kane, M.F., and Hendricks, J.D., 1982, Magnetic basement in the upper Mississippi embayment region-A preliminary report, in McKeown, F.A., and Pakiser, L.C., eds., Investigations of the New Madrid, Missouri, earthquake region: U.S. Geological Survey Professional Paper 1236, p. 39-53.

Hildenbrand, T.G., Kane, M.F., and Stauder, W., 1977, Magnetic and gravity anomalies in the northern Mississippi embayment and their spatial relation to seismicity: U.S. Geological Survey Miscellaneous Field Studies Map MF-914, scale 1:1,000,000.

Hildenbrand, T.G., Kucks, R.P., Kane, M.F., and Hendricks, J.D., 1980 , Aeromagnetic map and associated depth map of the upper Mississippi embayment region: U.S. Geological Survey Miscellaneous Field Studies Map MF-1158, scale 1:1,000,000.

Imlay, R.W., 1949, Lower Cretaceous and Jurassic formations of southern Arkansas and their oil and gas possibilities: Arkansas Division of Geology Circular 12, 106 p.

Jespersen, A., 1964, Aeromagnetic prospecting for bauxite in the Mississippi embayment, Arkansas and Missouri: U.S. Geological Survey Geophysical Investigations Map GP-37, scale 1:125,000.

Kane, M.F., Hildenbrand, T.G., and Hendricks, J.D., 1979, The Mississippi Valley graben, a hidden rift [abs.]: American Geophysical Union Transactions, v. 60, no. 46, p. 954.

1981, Model for the tectonic evolution of the Mississippi embayment and its contemporary seismicity: Geology, v. 9, p. 563-568.

Keller, G.R., and Cebull, S.E., 1973, Plate tectonics and the Ouachita system in Texas, Oklahoma, and Arkansas: Geological Society of America Bulletin, v. 83, p. 1659-1666.

Keller, G.R., and Shurbet, D.H., 1975, Crustal structure of the Texas Gulf Coastal Plain: Geological Society of America Bulletin, v. 86, p. 807-810.

Kidwell, A.L., 1951, Mesozoic igneous activity in the northern Gulf Coastal Plain: Gulf Coast Association Geological Society, 1st Annual Meeting Transaction, p. 182-199.

King, P.B., 1969, Tectonic map of North America: U.S. Geological Survey Map, scale 1:5,000,000.

Kisvarsanyi, E.B., 1974, Operation basement-Buried Precambrian rocks of Missouri-Their petrography and structure: American Association of Petroleum Geologists Bulletin, v. 58, p. 674-684.

Lillie, R.J., Nelson, K.D., de Voogd, B., Brewer, J.A., Oliver, J.E., Brown, L.D., Kaufman, S., and Viele, G.W., 1983, Crustal structure of Ouachita Mountains, Arkansas-A model based on integration of COCORP reflection profiles and regional geophysical data: American Association of Petroleum Geologists Bulletin, v. 67, no. 6, p. 907-931.

Lyons, P.L., 1961, Geophysical background of Arkoma Basin tectonics: Tulsa Geological Society Digest, v. 29, p. 94-104.

Malamphy, M.C., and Vallely, J.L., 1944, Geophysical survey of the Arkansas bauxite region: Geophysics, v. 9, no. 3, p. 324-365.

Mateker, E.J., Jr., 1959, Gravity and magnetic interpretation problems: St. Louis University M.S. thesis.

McCamy, K., and Meyer, R.P., 1966, Crustal results of fixed multiple shots in the Mississippi embayment, in Steinhart, J.S., and Smith, T.J., eds., The earth beneath the continents: American Geophysical Union Geophysical Monograph 10, p. 370-381.

Mellen, F.F., 1953, Mississippi's Black Warrior Basin yields gascondensate: World Oil, June 1953, p. 77-82.
Miser, H.D., 1959, Structure and vein quartz of the Ouachita Mountains of Oklahoma and Arkansas, in Cline, L.M., Hilseweck, W.J., and Feray, D.E., eds., The Geology of the Ouachita Mountains: Dallas Geological Society, Ardmore Geological Society, p. 30-39.

Miser, H.D., and Ross, C.S., 1925, Volcanic rocks in the Upper Cretaceous of southwestern Arkansas and southeastern Oklahoma: American Journal of Science, v. 9, p. 113-126.

Moody, C.L., 1949, Mesozoic igneous rocks of the northern Gulf Coastal Plain: American Association of Petroleum Geologists Bulletin, v. 33, no. 8, p. 1410-1428.

Morris, R.C., 1974, Sedimentary and tectonic history of the Ouachita Mountains: Society of Economic Paleontologists and Mineralogists Special Publication 22, p. 120-142.

Muehlberger, W.R., Hedge, C.E., Denison, R.E., and Marvin, R.F., 1966, Geochronology of the mid-continent region, United States, 3, southern area: Journal of Geophysical Research, v. 71, p. 5409-5426.

Nelson, K.D., Lillie, R.J., de Voogd, B., Brewer, J.A., Oliver, J.E., Kaufman, S., Brown, L., and Viele, G.W., 1982, COCORP seismic reflection profiling in the Ouachita Mountains of western Arkansas-Geometry and geologic interpretation: Tectonics, v. 1, no. 5 , p. $413-430$.

Nicholas, R.L., and Rozendal, R.A., 1975, Subsurface positive elements within Ouachita foldbelt in Texas and their relation to Paleozoic cratonic margin: American Association of Petroleum Geologists Bulletin, v. 59, no. 2, p. 193-216.

Nockolds, S.R., and Allen, R., 1954, The geochemistry of some igneous rock series: Geochemica et Cosmochimica Acta, v. 5, p. 245-285.

Peters, D.A., Lutter, W.J., Ginzburg, A., Walter, A.W., and Mooney, W.D., 1981, Deep structure of the Mississippi embayment from seismic refraction measurements, in Conference on the processes of planetary rifting: Universities Space Research Association, Lunar and Planetary Institute, p. 161-164.

Phelan, M.J., 1969, Crustal structure in the central Mississippi Valley earthquake zone: Washington University $\mathrm{Ph}$. D. thesis.

Pindell, James, and Dewey, J.F., 1982, Permo-Triassic reconstruction of western Pangea and the evolution of the Gulf of Mexico/Caribbean region: Tectonics, v. 1, no. 2 , p. 179-211.

Roeder, D.H., 1973, Subduction and orogeny: Journal of Geophysical Research, v. 78, p. 5005-5021.

Smith, J.R., 1974, Shallow igneous intrusion, Covington, Tennessee, as known from gravity and magnetic data: Nashville, Tenn., Vanderbilt University M.S. thesis, 50 p.

Society of Exploration Geophysicists, 1982, Gravity anomaly map of the United States, exclusive of Alaska and Hawaii east half: Society of Exploration Geophysicists, Tulsa, Oklahoma, scale $1: 2,500,000$.

Stewart, S.W., 1968, Crustal structure in Missouri by seismicrefraction methods: Seismological Society of America Bulletin, v. 58, p. 291-323.

Stone, C.G., and Sterling, P.J., 1964, Relationship of igneous activity to mineral deposits in Arkansas: Arkansas Geologic Commission Publication, $56 \mathrm{p}$.

Thomas, W.A., 1977, Evolution of Appalachian-Ouachita salients and recesses from reentrants and promontories in the continental margin: American Journal of Science, v. 277, p. 1233-1278.

Turner, F.J., and Verhoogen, J., 1960, Igneous and metamorphic petrology: New York, McGraw-Hill, 694 p.

Vernon, R.C., 1971, Possible future petroleum potential of pre-Jurassic, western Gulf basin: American Association of Petroleum Geologists Memoir 15, v. 2, p. 954-979.

Viele, G.W., 1979, Geologic map and cross section eastern Ouachita Mountains, Arkansas: Text accompanying Geological Society of America Map and Chart Series, MC-28F, p. 3-8. 
Walper, J.L., 1980, Tectonic evolution of the Gulf of Mexico, in Pilger, R.H., Jr., The origin of the Gulf of Mexico and the early opening of the central north Atlantic ocean: Louisiana State University Symposium, p. 87-98.

Warren, D.H., Healy, J.H., and Jackson, W.H., 1966, Crustal seismic measurements in southern Mississippi: Journal of Geophysical Research, v. 71, p. 3437-3467.

Washington, H.S., 1900, Igneous complex of Magnet Cove: Journal of Geology, v. 9, p. 607-622, 645-670.
White, G.W., 1980, Permian-Triassic continental reconstruction of the Gulf of Mexico-Caribbean area: Nature, v. 283, p. 823-826.

Wickham, J., Roeder, D.H., and Briggs, G., 1976, Plate tectonics models for the Ouachita foldbelt: Geology, v. 4, p. 173-176.

Williams, J.F., 1891, The igneous rocks of Arkansas: Arkansas Geological Survey Annual Report 1890, v. 2, 457 p.

Woollard, G.P., and Joesting, H.R., 1964, Bouguer gravity anomaly map of the United States: U.S. Geological Survey Map, 2 sheets, scale $1: 2,500,000$. 